\title{
MAŁŻEŃSTWO WARUNKOWE W ŚWIETLE KODEKSU PRAWA KANONICZNEGO I KODEKSU KANONÓW KOŚCIOŁÓW WSCHODNICH
}

Treść: Wprowadzenie. - 1. Pojęcie warunku. - 2. Rodzaje warunku. - 3. Geneza warunku. - 4. Warunek w Kodeksie Prawa Kanonicznego z 1917 r. - 5. Analiza kan. 1102 Kodeksu Prawa Kanonicznego z 1983 r. - 5.1. Wpływ na ważność małżeństwa warunku odnoszącego się do przyszłości. - 5.2. Wpływ na ważność małżeństwa warunku odnoszącego się do przeszłości lub teraźniejszości. - 6. Małżeństwo warunkowe według Kodeksu Kanonów Kościołów Wschodnich. - 6.1. Motu proprio Cerebrae allatae sunt. - 6.2. Analiza kan. 826 Kodeksu Kanonów Kościołów Wschodnich. - Zakończenie.

\section{Wprowadzenie}

Instytucja warunkowego aktu zgody występująca w Kodeksie Prawa Kanonicznego z 1983 r. ${ }^{1}$ i w Kodeksie Kanonów Kościołów Wschodnich z 1990 r. $^{2}$ wydaje się dość złożona, bowiem: „Małżeństwa zawierane pod warunkiem były zawsze w doktrynie Kościoła zagadnieniem trudnym i wywołującym rozbieżności zdań w tej materii"’3. Wyrażenie zgody małżeńskiej pod warunkiem stanowi okoliczność, która może spowodować nieważność małżeństwa, z tego też względu zaliczana jest do katalogu wad zgody małżeńskiej. W Kościele łacińskim podstawowe elementy kanonicznego pojęcia małżeństwa warunkowego pojawiły się w XII w., natomiast w Kościołach Wschodnich w XVIII w. KPK z 1983 r. uzależnia ważność małżeństwa od rodzaju

\footnotetext{
1 Codex Iuris Canonici auctoritate Ioannis Pauli PP. II promulgatus.

2 Codex Canonum Ecclesiarum Orientalium, Auctoritate Ioannis Pauli PP. II promulgatus, Typis Polyglottis Vaticanis 1990.

${ }_{3}$ M. Al. ŻUrowsKI, Kanoniczne prawo małżeńskie okresu posoborowego, Katowice 1976, s. 234.
} 
warunku, natomiast KKKW z 1990 r. odmawia ważności jakiemukolwiek małżeństwu zawartemu pod warunkiem.

\section{Pojęcie warunku}

Według niektórych autorów ,słowo warunek pochodzi od łacińskiego terminu conditio a raczej condicio i nie wywodzi się od cum dicere, lecz od pierwiastka dik (greckie deiknymi), co oznacza wykazywać i odpowiada pojęciu conditio (w najogólniejszym tego słowa znaczeniu), jako stanu osobowego, gospodarczego, również może oznaczać wymóg niezbędny do zaistnienia jakiegoś działania prawnego" ${ }^{4}$. KPK z 1983 r. w myśl zasady omnis definitio periculosa est nie przedstawia definicji warunku. Prawo cywilne natomiast pojęcie ,warunku” czerpie z prawa rzymskiego. Według encyklopedii popularnej PWN „warunek” w znaczeniu prawnym oznacza ,zastrzeżenie, przez które podejmujący czynność prawną uzależnia powstanie lub ustanie skutków tej czynności od zdarzenia przyszłego niepewnego"s.

Pojęcie „warunku” znaleźć można również w słowniku wyrazów obcych, z tym że termin ten ma wiele znaczeń i może być różnie pojmowany w zależności od kontekstu i okoliczności wypowiadania ${ }^{6}$. Jednakże pewne utrudnienie w pojmowaniu warunku w prawie kanonicznym może sprawiać kan. 1290 KPK z 1983 r., zgodnie z którym, jeżeli chodzi o kontrakty, nakazuje czerpać pojęcia i normy z prawa cywilnego, które przyjęte są na danym terenie także w stosunku do spraw kościelnych. Tak więc w sprawach dotyczących kontraktów i transakcji związanych z dobrami materialnymi stosuje się normy

${ }^{4}$ S. BiskUPSKI, Prawo matżeńskie kościoła rzymskokatolickiego, Warszawa 1956, s. 302 .

5 Encyklopedia popularna PWN, Warszawa 1982, s. 838.

${ }^{6}$ Stownik wyrazów obcych PWN, Warszawa 1980, s. 800. Słownik podaje następujące znaczenia pojęcia ,warunku”: warunek może być czynnikiem od którego uzależnione jest istnienie czegoś; warunkiem jest określone żądanie, wymaganie stawiane przy zawieraniu jakiejś umowy, od którego spełnienia zależy dotrzymanie, zrealizowanie czegoś; warunek może być utożsamiany z sytuacją, w której coś się dzieje; warunek to ogół cech warunkujących bycie kimś, czymś, upoważniających jednocześnie do wykonania czegoś; warunkiem jest zastrzeżenie mocą którego podejmujący czynność prawną uzależnia powstanie lub ustanie skutków tej czynności od zdarzenia przyszłego i niepewnego. 
prawa cywilnego ${ }^{7}$. Gdyby natomiast normy prawa cywilnego były sprzeczne z prawem Bożym, to nie mogą być stosowane, a ich miejsce zastępują odpowiednie normy prawa kanonicznego ${ }^{8}$. W systemie prawa cywilnego warunek pojmowany jest jako zdarzenie przyszłe i niepewne 9 . Warto zauważyć, iż istnieje różne pojmowanie terminu „warunek”. Niektórzy autorzy twierdza, że ,warunek” jest w pewnym sensie dodatkiem do aktu prawnego ${ }^{10}$, inni natomiast uważają, że w warunku istnieje zastrzeżenie lub oświadczenie woli, w którym strony coś zmieniają ${ }^{11}$. W prawie kanonicznym natomiast ważność dokonanego aktu uzależnia się od ,jakiejś okoliczności niepewnej w danej

${ }^{7}$ Kodeks cywilny (Dz. U. 1964 nr 16, poz. 3) w postanowieniu art. 89 przedstawia następującą definicję warunku: ,Z zastrzeżeniem wyjątków w ustawie przewidzianych albo wynikających z właściwości czynności prawnej, powstanie lub ustanie skutków czynności prawnej można uzależnić od zdarzenia przyszłego i niepewnego".

8 Warto przypomnieć postanowienie kan. 1290 KPK z 1983 r., które brzmi następująco: „To, co prawo państwowe na danym terytorium postanawia odnośnie umów zarówno w ogólności, jak i w szczególności oraz do zobowiązań, ma być zachowywane również mocą prawa kanonicznego w odniesieniu do rzeczy podlegających władzy rządzenia Kościoła, z tymi samymi skutkami, chyba że są przeciwne prawu Bożemu lub co innego zastrzega prawo kanoniczne przy zachowaniu przepisu kan. 1547'. Wydawałoby się, iż norma kan. 1290 KPK sugeruje, iż treść tej dyspozycji sprawia, że omawiane pojęcie jest jednakowe dla obu systemów prawnych, a prawo kanoniczne czerpie to pojęcie z prawa cywilnego. Oczywiście jest to błędne myślenie z uwagi na to, iż odmienne są źródła tego pojęcia w dwóch prawodawstwach. W systemie prawa cywilnego warunek ,Stanowi integralną, nierozłączną część czynności prawnej której dotyczy. Jego istotą jest uzależnienie powstania lub ustania skutków czynności prawnej od określonego zdarzenia". Z kolei dyspozycja kan. 1547 KPK z 1983 r. dopuszcza dowód ze świadków we wszystkich sprawach, ale zawsze pod kierownictwem sędziego. I chociaż istnieją różne koncepcje pojmowania warunku to z pewnością można powiedzieć, iż występuje zgodność co do tego, że jest nim: uzależnienie powstania i ustania skutków prawnych od zdarzenia przyszłego i niepewnego.

${ }^{9} \mathrm{~W}$ postanowieniu art. 89 Kodeksu cywilnego przedstawiono następującą definicję warunku: „Z zastrzeżeniem wyjątków w ustawie przewidzianych albo wynikających z właściwości czynności prawnej, powstanie lub ustanie skutków czynności prawnej można uzależnić od zdarzenia przyszłego i niepewnego".

10 S. Dmowski, S. Rudnicki, Komentarz do kodeksu cywilnego, Księga 1, część ogólna, Warszawa 2001, s. 293.

${ }_{11}$ Por. M. ŻurowsKi, Aktualna problematyka aktu warunkowego, Prawo Kanoniczne 18 (1975), nr 3-4, s. 88; D. STAFFA, De conditione contra matrimonii substantiam, Romanae 1955, s. 11. 
chwili dla nupturienta. Warunek może w różny sposób wpływać na ważność małżeństwa, w zależności od jego rodzaju"12.

\section{Rodzaje warunku}

KPK z 1983 r. odnośnie do zawarcia małżeństwa przewiduje trzy rodzaje warunków, czyli: warunek dotyczący przeszłości, teraźniejszości i przyszłości ${ }^{13}$. Niektórzy kanoniści natomiast wymieniają jeszcze inne rodzaje warunków, a mianowicie: warunek właściwy i warunek niewłaściwy, który z kolei dzieli się na warunek konieczny i niemożliwy, jak również przewidują istnienie warunku godziwego i niegodziwego, warunku rozwiązującego i zawieszającego, a także warunku wyraźnego, warunku domyślnego, warunku przyczynowego oraz warunku mieszanego czy też warunku potestatywnego i warunku sukcesywnego $^{14}$. Oznacza to, iż istnieje możliwość wyodrębnienia wielu

12 Por. T. Pawluk, Prawo kanoniczne wedtug Kodeksu Jana Pawła II, t. 3, Olsztyn 1996, s. 156; L.A. RobitTaILle, Conditioned consent: Natural law and human positive law, Studia Canonica 26 (1992), s. 75.

13 W. Góralski, Kanoniczne prawo matżeńskie, Warszawa 1985, s. 108. Autor podkreśla, iż: „W odniesieniu do małżeństwa zgodę wyrażoną warunkowo uznaje tylko prawo kanoniczne. Zawarcie małżeństwa pod warunkiem oznacza w prawie kanonicznym, że w samym kontrakcie, niejako jakby w jego części konstruktywnej, postawiono jakiś element czy okoliczność, od której samo istnienie kontaktu zależy". Zob. E. Sztafrowski, Chrześcijańskie matżeństwo, Warszawa 1985, s. 126. Autor wyjaśnia, iż: „warunek dotyczący przyszłości może być zawieszający lub rozwiązujący. Pierwszy zawiesza zgodę do czasu zaistnienia okoliczności, będącej przedmiotem warunku, np. nasze małżeństwo będzie ważne, jeśli uzyskasz dyplom studiów wyższych. Warunek rozwiązujący sprowadza się do tego, że ktoś odwołuje swoje zezwolenie z chwilą zaistnienia wymaganej okoliczności, np. rozejdziemy się w przypadku, gdy się okaże, że nasze charaktery są niedobrane". Poza tym zgodnie z poglądem tego autora warunek może być możliwy lub niemożliwy, a jest to uzależnione przede wszystkim od tego, czy okoliczność stanowiąca treść warunku może zaistnieć lub nie. Autor wymienia też warunek konieczny, w sytuacji, gdy okoliczność będąca przedmiotem warunku musi się zdarzyć, a także warunek niekonieczny, którego spełnienie zależy od woli człowieka.

${ }^{14}$ P. J. VILADrich, Konsens matżeński. Sposoby prawnej oceny i interpretacji w kanonicznych procesach o stwierdzenie nieważności matżeństwa (kanony 1095-1107 Kodeksu Prawa Kanonicznego), S. Świaczny (tłum.), Warszawa 2002, s. 369-372. Warto w tym miejscu przypomnieć stwierdzenia autora, który wyjaśnia znaczenie wielu typów warunków. I tak warunek właściwy, to taki, który „,charakteryzuje się decyzją nupturienta uzależniającą skuteczność jego konsensu od zaistnienia wydarzenia przyszłego i niepewnego". Warunkiem niewłaściwym zaś jest taki warunek, w którym „wydarzenie nie jest przyszłe albo nie jest niepewne”. Wobec tego autor wskazuje, iż 
form warunkowych, możliwych do zastosowania przez nupturientów w celu zabezpieczenia swej zgody ${ }^{15}$.

Warto zauważyć, że od warunku można odróżnić inne okoliczności, które nie mają wpływu na ważność małżeństwa i dość często mylone są ze zgodą warunkową. Z uwagi na to niektórzy autorzy podkreślają, iż: „Woli warunkowej nie można mylić z innymi różnymi dodatkami, które często towarzyszą zgodzie małżeńskiej konkretnego podmiotu" "16. Ponadto istotną sprawą jest fakt nieutożsamiania warunku chociażby z przyczyną, zobowiązaniem czy też demonstracją. $\mathrm{W}$ związku z tym w rzeczywistości różnica między wymienionymi terminami a warunkiem może być trudna do zauważenia, ponieważ

wśród „warunków niewłaściwych dotyczących przyszłości wyróżnia się warunki konieczne i niemożliwe: pierwsze to takie, w których wydarzenie, choć jest przyszłe, nie jest niepewne, ponieważ spełni się nieuchronnie (...) drugie to takie, w których wydarzenie, choć jest przyszłe, jest niemożliwe do zrealizowania”. Autor podkreśla, że znaczenie praktyczne posiadają warunki niewłaściwe „dotyczące przeszłości albo teraźniejszości (...), w których wydarzenie odnosi się do faktów z przeszłości albo zdarzeń teraźniejszych już dokonanych, ale o których nic się nie wie albo jeszcze się ich z całą pewnością nie stwierdziło”. Ponadto wyróżnia się warunki niegodziwe niekwalifikowane, w których ,wydarzenie jest obiektywnie niemoralne, jeśli nawet przyczyną tej niegodziwości lub nieuczciwości nie jest bezpośrednia sprzeczność z wartościami istotnej struktury małżeństwa”. Z kolei warunkami „niegodziwymi kwalifikowanymi albo contra substantiam nazywa się warunki, w których: „wydarzenie jest niemoralne wskutek bezpośredniej sprzeczności z elementami, przymiotami i istotnymi celami małżeństwa”. Pozostałe warunki są godziwe, „chociaż mogą być one nieodpowiednie albo nierozważne”. Warunek rozwiązujący występuje wtedy, gdy „,zamiarem podmiotu jest rozwiązanie węzła małżeńskiego od momentu, gdy wydarzenie się nie spełni" natomiast warunek będzie zawieszający, gdy ,intencją podmiotu jest zawieszenie powstania węzła małżeńskiego aż do momentu dokonania się wydarzenia”. Warunek wyraźny zaistnieje wtedy, gdy ,wola dołączenia go do zgody została wyrażona w formie oczywistej, jasnej, wyszczególnionej i określonej”. Warunek będzie domyślny lub ukryty, jeżeli ,pozytywną wolę dołączenia go, chociaż nie sformułowało się jej bezpośrednio, można z moralną pewnością wnioskować z innych faktów albo pewnych zachowań podmiotu”. Ponadto warunek może być przyczynowy, gdy „,spełnienie się wydarzenia nie zależy od woli ludzkiej” albo mieszany, gdy „wydarzenie zależy w części od woli ludzkiej i w części od przypadku”. Jednocześnie można wyróżnić warunek potestatywny, którego „wypełnienie zależy od woli drugiej zainteresowanej strony” lub sukcesywny, którego ,wypełnienie zależy od nieokreślonego kontynuowania dobrowolnego zachowania albo działania drugiej strony, albo nawet osoby trzeciej".

15 W. GóralsKi, Kanoniczne prawo..., s. 108.

16 P. J. Viladrich, Konsens matżeński. Sposoby prawnej oceny..., s. 372. 
zgodnie z tym, co twierdzą niektórzy autorzy: „Kluczem do ich odróżnienia jest - w przypadku wątpliwości - należyte odczytanie wolitywnej intencji podmiotu, uwzględniającej przede wszystkim słowa, przy pomocy których ona się wyraża. Chodzi o stwierdzenie, czy pod różnymi figurami i formami nie kryje się pozytywna intencja uzależnienia od nich powstania węzła"17. Wobec tego można powiedzieć, że główną różnica, jaka zachodzi pomiędzy warunkiem a przyczyną, czyli motywacją do zawarcia małżeństwa, jest właśnie to, iż przyczyna nie stanowi woli warunkowej w sytuacji, gdyby nawet była podstawowym motywem zawarcia małżeństwa.

W związku z naturą aktu prawnego istotne wydaje się uzyskanie odpowiedzi na następujące pytanie: czy na akt warunkowy składa się jeden akt woli wyrażony przez nupturienta (nupturientów), czy też na uzależnienie zgody przez wprowadzenie warunku potrzeba kilku aktów woli? Wyjaśnienie tej wątpliwości można uzyskać, posiłkując się poglądami niektórych kanonistów, którzy zgodnie uznaja, iż w akcie warunkowym nie istnieje podwójny akt woli, czyli jeden zgadzający się, a drugi zmieniający poprzedni, ponieważ: „Człowiek (...) zdolny do refleksyjnego działania - podobnie jak ma to miejsce przy symulacji, jednym aktem dokonuje aktu fałszywego, chociaż na zewnątrz jest on pozornie prawdziwy - tak samo tutaj jednym aktem uzależnia swoją zgodę na małżeństwo od okoliczności niepewnej" ${ }^{18}$. Poza tym należy zauważyć, że motywy działania nie są aktem warunkowym, z tym że powinny zaistnieć w podmiocie działającym, żeby samo działanie

17 Tamże.

18 D. StafFa, De conditione contra matrimonii..., s. 11. Według D. Staffa nie można robić rozróżnienia pomiędzy samą zgodą małżeńską, czyli samym aktem woli i jego przedmiotem, którym jest zgoda na prawdziwe małżeństwo. Ponadto w przypadku, gdyby przedmiot małżeństwa byłby inny, nie mielibyśmy do czynienia ze zgodą małżeńską w ścisłym tego słowa znaczeniu, lecz powstałby twór, którego nie moglibyśmy nazwać małżeństwem. Zob. F. CAPELlo, Tractatus canonico moralis. De sacramentis, vol. V, De matrimonio, Romanae 1961, s. 556. Według tego kanonisty przy akcie warunkowym zgoda jest skierowana równocześnie do dwóch przedmiotów, z których wybrany zostaje jeden, w zależności od spełnienia się okoliczności przyszłej niepewnej. Z kolei w sytuacji spełnienia się okoliczności lub zdarzenia przyszłego, od którego uzależnia się zgodę, strona zainteresowana wyraża zgodę i chce małżeństwa, w sytuacji przeciwnej natomiast nie godzi się na nie. Z uwagi na to podczas zaistnienia aktu warunkowego powinien zaistnieć motyw powodujący wyrażenie zgody i przyczyna, dla której zgodę się zawiesza albo neguje lub ogranicza. 
warunkowe miało sens. W związku z tym chociaż istnieją motywy podwójne, to i tak akt warunkowy jest czymś jednym ${ }^{19}$.

Ogromnie trudną kwestią jest ustalenie zaistnienia warunku, chociażby z tej racji, iż stanowi to podstawę do wydania wyroku przez sąd kościelny. Rota Rzymska natomiast, ustalając zgodę warunkową, wymienia kilka kryteriów, którymi są: przedmiot warunku, intencja osób, stan wątpliwości i reakcja na niespełnienie się warunku. Przedmiotem warunku jest uzależnienie zgody małżeńskiej od okoliczności przyszłej i niepewnej. Z kolei brak przedmiotu, od którego uzależnia się małżeństwo, $\mathrm{z}$ pewnością świadczy o niewystępowaniu warunku. $\mathrm{Z}$ uwagi na to warunek może doprowadzać do poważnych konsekwencji. Według niektórych autorów: „Łatwiej jest go udowodnić, jeśli

19 M. Al. ŻUrowski, Aktualna problematyka aktu warunkowego, Prawo Kanoniczne 18 (1975) nr 3-4, s. 91. Autor podkreśla, iż akt warunkowy nie istnieje u osoby, u której nie ma żadnych wątpliwości w chwili działania, niezależnie od tego, czy stan ten byłby wynikiem podstępu, czy też błędu. Zatem istotą aktu warunkowego jest: „uprzednie poznanie podwójnej możliwości, z których jedną zdecydowanie się wybiera a drugą odrzuca. Wątpliwość (...) nie musi być pozytywna ani specyficzna, wystarczy, aby była negatywna. Powstaje ona z braku pewności, czy w danym wypadku zdarzenie czy okoliczność, na której działającemu zależy, istnieje bądź nie”. Zob. P. J. VILADRIch, Konsens matżeński. Sposoby prawnej oceny i interpretacji..., s. 378. Autor podkreśla, że: „konsens uzależniony od warunku zawiera pozytywną wolę jednego lub obojga nupturientów zawieszenia skuteczności zgody, którą jednak się wyraża, do momentu spełnienia się czegoś, co nie tylko jest przyszłe, niepewne lub nieznane, ale jest zewnętrzne i niezależne w stosunku do woli małżeńskiej, i na co przenosi się powstanie węzła. (...) To roszczenie powoduje przerwanie ciągłości przyczynowej między momentem wyrażenia zgody, co się dokonuje, a momentem jej pełnej skuteczności, co się zawiesza. W tym przerwaniu bezpośredniej przyczynowości nie tylko istnieje anomalia chronologicznej separacji pomiędzy momentem wyrażenia zgody i momentem powstania węzła, z całym ryzykiem jakie niesie ze sobą zawieszenie węzła, fikcją prawną przenoszenia wstecz jego skutków i możliwością odwołania początkowej zgody. W rzeczywistości o wiele bardziej głębszą anomalią powstającą właśnie poprzez wolę podmiotu stawiającego warunek, jest przeniesienie wewnętrznej, wyłącznej i skutecznej siły konsensu do przyczyny zewnętrznej: niepewnego wydarzenia”. Wobec tego powstanie warunku powoduje przerwanie ciagłości pomiędzy momentem wyrażenia zgody a momentem jej pełnej skuteczności. Tak więc wola warunkowa zawiera inklinację woli nupturienta w kierunku niepewnego wydarzenia, którego istnienie jest do tego stopnia konieczne, iż tylko w sytuacji, kiedy dojdzie do jego spełnienia się, nupturient chce węzła małżeńskiego. Zatem można powiedzieć, iż istotą intencji warunkowej jest skierowanie woli nupturienta na spełnienie się wydarzenia niepewnego, ale koniecznego dla niego samego, ponieważ od jego realizacji będzie uzależniona jego zgoda. 
w odczuciu danej osoby jego przedmiot jest sprawą doniosła, wchodzi w zakres substancji przyszłego małżeństwa lub kiedy stawiano go w powiązaniu z istotnymi przymiotami życia małżeńskiego"20.

Rota Rzymska do kryteriów ustalania warunku zalicza także wątpliwość. Z analizy wyroków rotalnych wynika, że pozytywna wątpliwość początkowa nie jest absolutnie konieczna do występowania warunku, ponieważ wystarczy wątpliwość negatywna, która wynika z braku pewności odnośnie do wystąpienia pewnych okoliczności czy też cech, od których chce uzależnić kontrakt. Jednocześnie należy zauważyć, iż warunku nie stawia się koniecznie z racji niepokoju albo wątpliwości, tylko wskutek przezorności w formie zabezpieczenia się przed czymś, czego się właściwie nie zna dobrze ${ }^{21}$. Poza tym watpliwość początkowa nie jest koniecznie wymagana przy stawianiu warunku, a przecież może dojść do tego, że sam warunek wystąpi bez wątpliwości ${ }^{22}$. Wobec tego można powiedzieć, iż z orzecznictwa Roty Rzymskiej wynika, że określenie odpowiednich kryteriów, na podstawie których należy oceniać postawiony warunek, ma istotne znaczenie w sądownictwie kościelnym, ponieważ ułatwia tym samym sędziom przeprowadzenie postępowania dowodowego na okoliczność właśnie powstania warunku.

\section{Geneza warunku}

Instytucja małżeństwa zawieranego pod warunkiem ma swój początek w prawie kościelnym. I chociaż prawo rzymskie znało pojęcie warunku, zwłaszcza przy działaniu prawnym, to z całą pewnością dotyczył on przyszłości, natomiast nie była znana instytucja małżeństwa zawieranego pod warunkiem. W Księgach Starego Testamentu zaś można znaleźć przykłady aktu warunkowego ${ }^{23}$. W prawie żydow-

20 J. LASKowsKi, Matżeństwo zawierane warunkowo $w$ świetle wyroków Roty Rzymskiej, Prawo Kanoniczne 24 (1981) nr 1-2, s. 180.

${ }_{21}$ Por. SRR. Dec., vol. 44 z dnia 9 grudnia 1952 r., c. Brennan, s. 657, nr 9; SRR Dec., vol. 54 z dnia 14 listopada 1968 r., c. Pinna, s. 1962, nr 3; SRR Dec., vol. 60 z dnia 15 grudnia 1968 r., c. Mattioli, s. 865, nr 3.

22 Por. SRR. Dec., vol. 22 z dnia 22 lutego 1940 r., c. Rogers, s. 232, nr 300; SRR. Dec. vol. 48 z dnia 20 listopada 1956 r., c. Pasquazi, s. 906, nr 4; SRR. Dec., vol. 219 z dnia 23 listopada 1971 r., c. Rogers, s. 337, nr 47; SRR. Dec., vol. 20 z dnia 23 lutego 1976 r. c. Pinto, s. 4784, nr 6.

${ }^{23}$ Pismo Święte Starego i Nowego Testamentu, Księga Kapłańska 26,3. Warto przytoczyć fragment tekstu, gdzie napisano, iż: „Jeżeli będziecie postępować według 
skim wewnętrzna intencja nie miała znaczenia, dlatego też nie miała wpływu na ważność lub nieważność aktu. W praktyce dość często przy akcie zaślubin dodawano jakiś warunek, od którego spełnienia zależała ważność czy też nieważność danego związku małżeńskiego, zwłaszcza wtedy, gdy był to warunek, który odnosił się do stanu aktualnego, a mianowicie był to warunek dotyczący teraźniejszości. $\mathrm{W}$ takiej sytuacji, gdyby doszło do niewypełnienia się warunku, to małżeństwo uważane byłoby za nieważne - wówczas żona mogłaby zostać oddalona bez tzw. listu rozwodowego ${ }^{24}$.

Jeżeli chodzi o źródła prawa kanonicznego, zwłaszcza okresu dekretałowego, to nie można wskazać na występowanie regulacji dotyczących aktu warunkowego. Niemniej jednak nie można też całkowicie wykluczyć nawet minimalnego wpływu prawa rzymskiego, chociaż nie istnieją na to dowody. Używanie warunku szczególnie w prawie rzymskim nie było dość często stosowane, ale zdarzały się przypadki występowania warunku, z tym że w przypadku zwykłych kontraktów, nie można natomiast wskazać, że stosowano warunek do małżeństwa. Niektórzy autorzy wyjaśniają to tym, iż wówczas nie można było do umowy dołączyć warunku, z uwagi na to, że małżeństwo zawierane było poprzez uroczysty akt, który składał się z coemitio i confarreatio, jak również z tej racji, iż małżeństwo powstawało ze stypulacji, a ten akt nie przyjmuje warunków zależnych od niepewnego zdarzenia ${ }^{25}$. Problematykę dotyczącą warunku można znaleźć przy okazji zawierania zaręczyn. I chociaż początkowo zabraniano warunkowego zawierania zaręczyn, to później zostało to zmienione i dopuszczano tę

moich ustaw i będziecie strzegli przykazań moich wprowadzając je w życie, dam wam (...)". Jeżeli lub będzie wierny Bogu, to on da mu urodzaj, plony, pokój, itp. W dalszej części tekstu stwierdzono, że: „Jeżeli zaś nie będziecie mnie słuchać i nie będziecie wykonywać tych wszystkich nakazów, jeśli będziecie gardzić moimi ustawami, jeżeli będziecie się brzydzić moimi wyrokami tak, że nie będziecie wykonywać moich nakazów i złamiecie moje Przymierze, to ja obejdę się z wami odpowiednio (...)". Następnie Bóg wymienia konsekwencje takiego postępowania, czyli mówi o nieurodzaju i coraz cięższych karach. Wynika z tego, iż postępowanie Boga uzależnione jest od postępowania ludu izraelskiego. Można powiedzieć, że warunek ten uzależniony od działania jednej ze stron.

${ }^{24}$ R. WeIgand, Die bedingte Eheschliessung im kanonischen Recht, München 1963, s. 86.

25 W. WoŁodkiewicz, Prawo rzymskie, Warszawa 1993, s. 89. 
formę, z tym że pod warunkiem godziwym, ale nie zezwalano na małżeństwo pod warunkiem ${ }^{26}$.

Zastanawiając się nad problematyką dotyczącą małżeństwa warunkowego istotne wydaje się przypomnienie dwóch tekstów, które z pewnością nie są związane z instytucją małżeństwa warunkowego, ale mogą stanowić podłoże rozwoju tej instytucji. Pierwszy pochodzi z synodu partykularnego, natomiast drugi od Świętego Augustyna. W obu tekstach chodzi o zawarcie zaręczyn, które zawierane są, ale pod warunkiem nawrócenia, czyli przyjęcia chrześcijaństwa. I chociaż nie chodzi w tej sytuacji o małżeństwo warunkowe, bo nawet gdyby było zawarte, to z pewnością byłoby nieważne z racji przeszkody, jaką byłby związek z osobą nieochrzczoną ${ }^{27}$. Niemniej jednak wpływ na wypracowanie koncepcji małżeństwa warunkowego ma tzw. Szkoła Paryska, która przyczyniła się do opracowania i wyjaśnienia terminów związanych z warunkiem przeciwnym istocie małżeństwa ${ }^{28}$. Zgodnie z opinią niektórych autorów instytucja małżeństwa warunkowego ma swój początek w XII w., bowiem wówczas zaczęła upowszechniać się doktryna stwierdzająca, iż zgoda jest przyczyną sprawczą małżeństwa, dlatego też rozumienie małżeństwa jako umowy pozwalało stosować do niego reguły prawa rzymskiego, które dotyczyły warunku ${ }^{29}$.

Rozważając w dalszym ciągu problematykę związaną z małżeństwem warunkowym, należałoby przypomnieć doktrynę scholastyczną, w której występują trzy opinie na temat stosowania warunku. Pierwsza opinia stwierdza, iż warunek dodany do zgody małżeńskiej pozostaje bez skutku prawnego. Druga opinia zaś wskazuje na to, że każdy warunek doprowadza do tego, że małżeństwo staje się nieważne. Trzecia natomiast, przeważająca, bo od 1222 r. dopuszczała istnienie zgody warunkowej w małżeństwie i właśnie ona została przyjęta przez jurysprudencję $e^{30}$. Jednakże podstawowe elementy kanonicznego pojęcia małżeństwa warunkowego zostały przedstawione w XII w. przez

${ }^{26}$ M. Al. Żurowski, Kanoniczne prawo matżeńskie okresu..., s. 115.

${ }^{27}$ M. Al. Żurowski, Powstanie kanonicznej koncepcji warunkowego zawarcia malżeństwa, Analecta Cracoviensia 7 (1975), nr 1, s. 495.

28 M. Al. ŻurowsKi, Kanoniczne prawo matżeńskie okresu..., s. 115.

29 Por. W. Góralski, Kanoniczne prawo..., s. 209.

${ }^{30}$ Por. J. PRADER, Il consenso matrimoniale condizionato nella disciplina canonica Latina e orientale, w: Iustus Iudex, Festgabe für Paul Wessemann zum 75, Geburstag von seinen Freuden und Schülern, Essen 1990, s. 280. 
papieża Innocentego IV. Ojciec św. dopuszczał możliwość zawarcia zarówno zaręczyn, jak i małżeństwa pod warunkiem, z tym że w sytuacji powstania warunku godziwego. Poza tym papież Innocenty IV stwierdził, iż w takiej sytuacji ważność małżeństwa zostaje zawieszona, dopóki okoliczność przyszła i niepewna nie spełni się ${ }^{31}$. Podobnie Henryk de Segusio w dziele zatytułowanym Summa potwierdza możliwość zawieszenia ważności zaręczyn lub małżeństwa, ale w sytuacji, gdyby wystąpił warunek możliwy i godziwy, z kolei do innych kontraktów nakazuje stosować koncepcję rzymską ${ }^{32}$.

Z kolei dekretały Grzegorza IX z 1234 r. przedstawiają trzy kategorie warunku. Pierwszy to warunek niemożliwy i niegodziwy, a więc taki, który uznaje się za niepostawiony. Drugi natomiast to warunek przeciwny istocie małżeństwa, czyli taki, który powoduje nieważność. Trzeci zaś to warunek godziwy i możliwy, który zawiesza zgodę małżeńską do chwili spełnienia się warunku. Poglądy zawarte w dekretałach upowszechniły się i przetrwały do czasów Kodeksu Prawa Kanonicznego z 1917 r. ${ }^{33}$ Zatem można powiedzieć, iż z analizy materiałów źródłowych wynika jednoznacznie, że już od XIII w. w kanonistyce funkcjonuje pogląd na istnienie odrębnego pojęcia warunkowego zawarcia małżeństwa, w którym od okoliczności przyszłej i niepewnej uzależniona jest ważność zawartego małżeństwa, a więc jego istnienie, a nie skuteczność, jak to miało miejsce w prawie rzymskim. W takiej też formie po pewnych niewielkich zmianach instytucja aktu warunkowego znalazła swoje miejsce w prawie kościelnym.

\section{Warunek w Kodeksie Prawa Kanonicznego z 1917 r.}

Problematyka małżeństwa warunkowego w Kodeksie Prawa Kanonicznego z 1917 r. została uregulowana w postanowieniu kan. 1092 ${ }^{34}$. $\mathrm{Z}$ treści tego kanonu wynika, że: „Warunek raz postawiony i nieodwołalny: $\S 1$. Jeżeliby odnosił się do przyszłości i był konieczny, albo

31 Cytuję za M. Al. Żurowski, Powstanie kanonicznej koncepcji..., s. 506. Innocentinus IV, In quinque libros decretalium, X, 4, 5, 1, Lungduni 1578, s. 304.

${ }^{32}$ Cytuję za M. Al. ŻUrowski, Kanoniczne prawo matżeńskie..., s. 201. Henricus de Segusio, Summa Aurea IV, de conditionibus appositis in desponsatione vel allis contractibus, nr 12, Lyon 1537, s. 204.

${ }_{33}$ M. Al. Żurowski, Kanoniczne prawo matżeńskie okresu..., s. 144.

${ }^{34}$ Codex Iuris Canonici P II X Pontifices Maximi iussu digestus Benedicti Papae XV auctoritate promulgatus, AAS 9 (1917), p. II. 
niemożliwy bądź też niegodziwy, ale nie przeciw istocie małżeństwa, należy uważać jako nie postawiony. $§ 2$. Jeżeliby odnosił się do przyszłości a był przeciw istocie małżeństwa, sprawia że jest ono nieważne. $\S 3$. Jeżeliby odnosił się do przyszłości a był godziwy, ważność małżeństwa zawiesza. § 4. Jeżeliby odnosił się do przeszłości albo teraźniejszości, małżeństwo będzie ważne lub nie, o ile to, co podpada pod warunek, istnieje lub nie". Przedstawiona dyspozycja stwierdza, iż ważność małżeństwa była uzależniona od rodzaju aktu warunkowego. Ówczesne przepisy kodeksowe zawierały trzy kategorie warunków, czyli: warunek odnoszący się do przyszłości, teraźniejszości i przeszłości. Poza tym warto zaznaczyć, że zapisy KPK z 1917 r. przewidywały także pewne ich odmiany. Niemniej jednak w rzeczywistości sformułowanie postanowienia kan. 1092 okazało się skomplikowane, a niektórych przypadkach nawet bardzo niejasne z uwagi na to, iż inspirowało się równocześnie trzema opcjami prawnymi, które zostały wyżej przedstawione.

Zastanawiając się nad normą kan. 1092 § 1 KPK z 1917 r., można dojść do wniosku, że prawodawca sugerował się poglądem, zgodnie z którym dołączenie na serio do zgody małżeńskiej warunku niemożliwego do spełnienia się, ale który będzie również można udowodnić, doprowadzi do nieważności małżeństwa, ponieważ w ten sposób uwarunkowana zgoda nie istnieje i istnieć nie będzie. Ponadto wydaje się, że nikt rozsądny w sprawie ogromnie istotnej, jaką jest przecież małżeństwo, nie będzie stawiał warunku, który musi się spełnić lub jest niemożliwy do spełnienia, chociażby z uwagi na to, iż postawienie takiego warunku będzie postępowaniem niegodziwym ${ }^{35}$.

${ }_{35}$ M. Al. Żurowski, Kanoniczne prawo matżeńskie Kościoła Katolickiego, Katowice 1987, s. 143. Zob. P. J. VILADRICH, Konsens matżeński..., s. 383 - 384. Autor zaznaczył, że co do warunków dotyczących przyszłości, koniecznych, niemożliwych i niegodziwych niekwalifikowanych zastosowano kryterium uznania je za niepostawione. Poza tym wyjaśnił, iż: „W rzeczywistości, jeżeli udowodniło się, że nupturient poważnie postawił warunek, uważając to, co konieczne za niepewne, to co niemożliwe za możliwe i naprawdę chcąc tego, co niegodziwe niekwalifikowane, wówczas takie warunki, które prawo uznawało jako nie postawione, były oceniane przez doktrynę i orzecznictwo jako rzeczywiście dołączone, pozostawiając w zawieszeniu powstanie węzła aż do spełnienia się wydarzenia koniecznego lub niegodziwego i powodując nieważność małżeństwa w przypadku wydarzenia obiektywnie niemożliwego". Istotna kwestią na którą należy zwrócić uwagę był fakt dotyczący sprzeczności między przepisem prawa a praktyką orzeczniczą odnośnie warunków nie postawionych. Poza 
W analizowanym postanowieniu prawodawca wskazuje, że w sytuacji, gdyby zaistniał warunek konieczny, to: „małżeństwo byłoby ważne lub ważność byłaby zawieszona aż do czasu spełnienia się go. Ponieważ w tym wypadku realizacja warunku jest pewna, nie będzie on miał charakteru warunku w ścisłym tego słowa znaczeniu. Raczej oznaczałby termin, od którego małżeństwo zacznie obowiązywać"36.

Postanowienie kan. 1092 § 2 KPK z 1917 r. dotyczy postawienia warunku przyszłego, ale przeciwnego samej istocie małżeństwa, któremu prawodawca odmawia ważności aktu dokonanego pod właśnie takim warunkiem. Z kolei, gdyby warunek nie był przeciwny istocie małżeństwa, to byłby uznawany za niedodany. Niektórzy autorzy tłumaczą, że warunkiem przeciwnym istocie małżeństwa jest warunek, który niweczy samą umowę małżeńską, z tego też względu warunek może albo zwracać się przeciwko prawu stron w stosunku do siebie, albo być skierowany przeciwko trwałości tego prawa, jak również przeciw jego jedności ${ }^{37}$. Inni kanoniści natomiast podkreślają, iż wa-

tym Autor podkreśla, iż ważną sprawą było to, że przyjęcie „z tytułu domniemania iuris tantum - warunków koniecznych i niemożliwych wywołało rujnującą dezorientację wobec prawdziwej woli małżeńskiej i powagi intencji warunkowej”. Ponadto Autor dodaje, że: „obiektywna niemoralność warunków niegodziwych niekwalifikowanych powodowała, iż do konsensu - uznawanego iuris tantum za ważny - dołączano całe mnóstwo elementów niegodziwych, niemoralnych i nieuczciwych, których zdolność do współistnienia z prawdziwą wolą małżeńską i możliwość a fortiori uzależnienia od nich samego powstania sakramentu małżeństwa ich istnienia była wręcz skandaliczna".

${ }^{36}$ M. AL. Żurowski, Kanoniczne prawo matżeńskie okresu ..., s. 293-294.

37 S. BISKuPski, Prawo matżeńskie kościoła rzymskokatolickiego, Warszawa 1956, s. 306. Warto zaznaczyć, że warunki niegodziwe kwalifikowane, a więc sprzeczne $\mathrm{z}$ istota małżeństwa rozpatrywane $\mathrm{w} \S 2$ postanowienia kan. $1092 \mathrm{KPK}$ z 1917 r. zostały potraktowane zgodnie z taką opcją prawną, która odmawia ważności zgodzie uzależnionej od takich warunków. Jednocześnie należy zauważyć, że w tradycji kanonicznej już od dekretału Si condiciones papieża Grzegorza IX nie było żadnej wątpliwości co do tego, że taki właśnie konsens jest nieważny. W związku z tym, jeśli chodzi o rzeczywistą podstawę nieważności, to zarówno doktryna, jak i orzecznictwo zaczęły wyjaśniać, że warunki contra substantiam były prawdziwymi pozytywnymi wykluczeniami małżeństwa lub jego istotnych części, z tym, że w praktyce przybierały postać pozornego warunku. Zob. P. J. VILADRICH, Konsens matżeński..., s. 381 i 384-385. Autor podkreśla, że: ,jeżeli anomalie wprowadzane do systemu przez zgodę warunkową są dlań zbyt uciążliwe - jest uznanie, że ten typ zgody - zawarcie małżeństwa pod warunkiem - jest radykalnie przeciwny albo przynajmniej poważnie nieodpowiedni w stosunku do natury małżeństwa kanonicznego; w konsekwencji pra- 
runek taki musiał być postawiony pozytywnym aktem woli, ponieważ: „Pozytywny akt woli, przez który wyklucza się wszelkie prawo do aktu małżeńskiego ma miejsce wówczas, jeżeli kontrahent ma intencję zawarcia małżeństwa, lecz jednocześnie wyklucza pozytywnie wszelkie zobowiązanie do aktów zdatnych samo przez się do zrodzenia potomstwa" 38 .

Z kolei z dyspozycji kan. 1092 § 3 KPK z 1917 r. wynika, że gdyby warunek był godziwy i odnosił się do przyszłości, to wówczas zawieszałby ważność małżeństwa do chwili spełnienia się warunku. W związku z tym, aby można było w sposób godziwy postawić taki warunek, musiałaby istnieć dość istotna kwestia do tego, aby doszło do zawarcia tego małżeństwa, jak również musiałby istnieć jakiś powód do tego, aby można było czekać na spełnienie się warunku ${ }^{39}$.

wodawca może zdecydować o nie uznaniu ważności małżeństw ustanowionych poprzez zgodę warunkową, niezależnie od tego, czy warunek się zweryfikuje, czy nie. To rozwiązanie jest korzystne na tyle, że likwiduje anomalię w systemie małżeńskim zgody warunkowej, bez ryzyka zastąpienia jej wolą prawa. Jednak to rozwiązanie zakłada nie uznanie prawdziwej woli małżeńskiej, która przecież istnieje, karcąc niejako bardziej perypetie biograficzne skłaniające nupturienta ze słusznej przyczyny do dołączenia warunku, niż brak prawdziwej woli małżeńskiej”. Poza tym warto dodać, że Instrukcja Kongregacji Sakramentów z dnia 29 czerwca 1949 r. wprowadziła wymóg wcześniejszej konsultacji i zgody Ordynariusza miejsca do godziwego dołączenia warunków. Autor wyjaśnia, że: „w odróżnieniu od autentycznej intencji małżeńskiej, choćby jej skuteczność była uzależniona od istnienia niepewnego wydarzenia (...) warunkach contra substantiam od samego początku nie ma prawdziwej woli małżeńskiej, lecz jej wolitywna nieobecność całkowita albo częściowa, ponieważ taki warunek polega właśnie na pragnieniu braku całkowitego albo częściowego, ale w każdym razie istotnego. (...) zupełna lub częściowa nieobecność istoty małżeństwa nie może być wydarzeniem niepewnym (...) nie może zaistnieć prawdziwa intencja małżeńska, chociaż uzależniona od warunku (...) wola małżeństwa i równocześnie wola nieobecności jego istoty jest oczywistą sprzecznością - bez większych trudności wnioskuje się, że (...) warunki contra substantiam nie są prawdziwymi warunkami, chociaż prawodawca uznaje nieważność konsensu od nich uzależnionego (...) stanowią autentyczne wykluczenia symulacyjne zgody i to jest bardziej trafny fundament nieważności małżeństwa w ten sposób zawartego".

38 W. SzAFrańsKi, Motywy prawne z tytułu warunku przeciwko istocie małżéstwa, Polonia Sacra 4 (1955), s. 392.

39 Instrukcja o kanonicznym badaniu narzeczonych, Olsztyn 1946, nr 39, s 21. Warto zaznaczyć, że Instrukcja Episkopatu o kanonicznym badaniu narzeczonych z dnia 9 września 1946 r. przewidywała w sytuacji postawienia warunku godziwego konieczność zbadania, czy zainteresowany chce w sposób godziwy sprawdzić urzeczywistnienie się warunku. Wobec tego, jeśli wszystkie elementy istnieją, to wów- 
Postanowienie kan. 1092 § 4 KPK z 1917 r. wprowadza zasadę dotyczącą tego, że małżeństwo zawarte pod warunkiem odnoszącym się do przyszłości lub teraźniejszości jest ważne lub nie w zależności od tego, czy jego przedmiot istnieje, czy też nie. Wprowadzenie tego typu warunków wynikało z uznania, że małżeństwo ma charakter umowny, bowiem wzięto pod uwagę fakt, że skoro w innych umowach uznaje się warunki co do przeszłości i teraźniejszości, to z tego też względu należy je uznać także w małżeństwie. Wobec tego, gdyby istniała możliwość dodania warunku godziwego odnoszącego się do przeszłości lub do teraźniejszości, małżeństwo byłoby ważne lub nie w zależności od tego, czy to, co zastrzeżono, istnieje, czy też nie. $\mathrm{Z}$ pewnością stosowanie tego postanowienia kodeksowego nie budziło żadnych wątpliwości, z tym że trudności nasuwały się wtedy, gdy chodziło o warunki niegodziwe albo niemożliwe do spełnienia. Dlatego też warto przypomnieć wypowiedź św. Tomasza, który wyjaśnił, że: ,jeżeli warunek jest czasu teraźniejszego a nie sprzeciwia się małżeństwu, godziwy czy niegodziwy, małżeństwo istnieje, gdy przedmiot warunku istnieje, nie ma małżeństwa, gdy i przedmiotu warunku nie ma"40.

czas do godziwego zawarcia małżeństwa warunkowego wymagane było dodatkowe zezwolenie ordynariusza. Zob. P. J. Viladrich, Konsens matżeński..., s. 385-386. Autor wyjaśnia, że: „warunki godziwe dotyczące przyszłości sprawiły w zgodzie wszystkie charakterystyczne skutki właściwego warunku, włącznie z ich anomaliami, czyli istnienie zgody małżeńskiej aktualnie wyrażonej, chociaż z zawieszoną skutecznością, rozłam między in fieri i in facto esse, wolitywne przeniesienie skutecznej władzy na przyczynę zewnętrzną - wydarzenie przyszłe i niepewne - przeniesienie efektów wstecz przy użyciu fikcji prawnej z momentu spełnienia się wydarzenia do początkowego momentu wyrażania konsensu, a w międzyczasie możliwość odwołania wyrażonej zgody". Jednocześnie odpowiada na następujące pytanie, czyli: czym w rzeczywistości jest zgoda wyrażona lecz możliwa do odwołania? Autor stwierdza, że: „dylematem (...) była dopuszczalność konsensu możliwego do odwołania i jego zgodność z naturą i szczególną mocą małżeństwa sakramentalnego. Problem ten znika w stosunku do zgody podporzą̧kowanej warunkowi dotyczącemu przeszłości i teraźniejszości, ponieważ w tych sytuacjach wydarzenie już się dokonało w momencie wyrażenia zgody, chociaż podmiot trwa w niepewności co do tego, wskutek czego małżeństwo jest ważne albo nieważne w zależności od tego, czy istnieje lub nie przedmiot warunku, przy czym akceptacja tego typu zgody warunkowej nie powoduje obiektywnego zawieszenia powstania węzła małżeńskiego".

${ }^{40}$ M. Al. Żurowski, Kanoniczne prawo matżeńskie Kościoła..., s. 296. Autor wyjaśnia, że Thomas Sanchez w stosunku do warunków niegodziwych ustala tę samą zasadę co św. Tomasz, z tym że w stosunku do warunków niemożliwych i zgodnie 
Z przedstawionych rozważań na temat pojmowania warunku w KPK z 1917 r. wynika, że zapisy kodeksowe dopuszczały zawieranie małżeństwa pod warunkiem godziwym dotyczącym przyszłości. Można zatem powiedzieć, że warunek ten zawieszał ważność małżeństwa do czasu spełnienia się okoliczności. Tak więc, jeżeli warunek nie spełnił się, to zgoda małżeńska stawała się bezskuteczna. Wobec tego małżeństwo można było uzależnić tylko od warunku zawieszającego, a nie rozwiązującego. Z kolei gdyby postawiono warunek rozwiązujący, to małżeństwo byłoby od początku nieważne, z tej racji, że warunek taki jest sprzeczny z istotnym przymiotem małżeństwa, jakim jest nierozwiązalność.

\section{Analiza kan. 1102 Kodeksu Prawa Kanonicznego z 1983 r.}

Rozważania dotyczące postanowienia kan. 1102 KPK z 1983 r. ${ }^{41}$ będą obejmowały poszczególne typy warunku, bowiem prawodawca kościelny w nowym kodeksie nie eliminuje całkowicie małżeństwa warunkowego, można powiedzieć, że nawet uważa, iż warunek jest i będzie zawsze obecny w małżeństwie. Z tego też względu należy zastanowić się nad problematyką dotyczącą warunku odnoszącego się od przyszłości oraz warunku odnoszącego się do przeszłości i teraźniejszości.

\footnotetext{
z jego opinią należy je odrzucić. Poza tym podkreślono, że tezę tę popierał wybitny kanonista Piotr Gaspparri. Jednocześnie zaznaczono, że zapisy kodeksowe z 1917 r. nie wprowadzają żadnego rozgraniczenia pomiędzy warunkiem godziwym i niegodziwym, możliwym do spełnienia i niemożliwym, odnoszącym się do teraźniejszości i przyszłości, i to bez żadnej różnicy stwierdza, że małżeństwo jest ważne lub nie, jeśli przedmiot warunku istnieje lub nie istnieje w chwili zawierania małżeństwa. Wobec tego można wysunąć wniosek, że wszystkie warunki co do teraźniejszości i przeszłości należało traktować w jednakowy sposób.

${ }^{41}$ Postanowienie kan. 1102 KPK z 1983 r. brzmi następująco: „§ 1. Nie można ważnie zawrzeć małżeństwa pod warunkiem dotyczącym przyszłości. § 2. Małżeństwo zawarte pod warunkiem dotyczącym przeszłości lub teraźniejszości jest ważne lub nie, zależnie od istnienia lub nieistnienia przedmiotu warunku. $\S 3$. Warunek zaś, o którym mowa w $\S 2$, nie może być godziwie dołączony, chyba że za pisemną zgodą ordynariusza miejsca".
} 


\subsection{Wpływ na ważność małżeństwa warunku odnoszącego się do przyszłości}

Nowe spojrzenie na problematykę związaną z zawieraniem małżeństwa pod warunkiem dotyczącym przyszłości zostało wprowadzone w KPK z 1983 r. Można powiedzieć, że po pierwsze prawodawca kościelny chciał uniknąć podważenia zasady nieodwołalności zgody małżeńskiej wyrażonej w postanowieniu kan. $1057 \S 2^{42}$, z uwagi na to, że zezwolenie na zawarcie związku małżeńskiego pod warunkiem dotyczącym przyszłości spowodowałoby oddalenie skuteczności zgody w czasie, a więc ważność małżeństwa byłaby zawieszona do momentu spełnienia się warunku. Dlatego też prawodawca kościelny, wprowadzając takie uregulowanie, chciał wyeliminować stan niepewności, jaki z pewnością mógłby powstać. Poza tym mogłaby wówczas powstać wątpliwość, czy takie małżeństwo istnieje, czy też nie. Po drugie natomiast prawodawca kościelny chciał wyeliminować różnego rodzaju anomalie, które mogłyby powodować akceptację stanu zawieszenia między wyrażeniem zgody a zaistnieniem węzła małżeńskiego, oczywiście nie na skutek możliwości odwołania konsensu, ale przede wszystkim z uwagi na problemy doktrynalne i niewyjaśnione sytuacje faktyczne możliwego dopełnienia małżeństwa. W obecnych zapisach kodeksowych dwa wymienione cele łączą się ${ }^{43}$. W związku

${ }^{42}$ Zgodnie z dyspozycją tego przepisu „Zgoda małżeńska jest aktem woli, którym mężczyzna i kobieta w nieodwołalnym przymierzu wzajemnie się sobie oddają i przyjmują w celu stworzenia małżeństwa".

${ }^{43}$ P. J. Viladrich, Konsens matżeński..., s. 387-388. Autor podkreśla, że: „Opcja prawodawcy za nie uznaniem ważności warunku dotyczącego przyszłości, z powodu niejasnych i skomplikowanych sytuacji, które stwarza ten typ warunków, mimo że jest ze wszech miar słuszna i uzasadniona, jest tylko z Prawa pozytywnego. (...) uznanie, że zgoda odwołalna nie jest prawdziwą zgodą małżeńską, wyraża lepsze poznanie Prawa naturalnego i w nim ma swój fundament”. Poza tym Autor zaznacza, że: „odwołalna zgoda, która (...) została wyrażona warunkowo - zawiera zastrzeżenie wewnętrznej możliwości odwołania, na co pozwala stan zawieszenia zgody wskutek warunku dotyczącego przyszłości, uznawana jest przez prawodawcę za nieważną z Prawa naturalnego, ponieważ nie uznaje się jej za prawdziwą zgodę małżeńską". Autor jednocześnie wyraża następujący pogląd: „gdy zaistnieje taka intencja zastrzeżenia sobie odwołania zgody, mamy do czynienia z konsensem nieważnym, nie tylko przez intencję warunkową, ile przez brak prawdziwej zgody, a w związku z tym mamy do czynienia z przypadkiem wykluczenia z kan. $1101 \S 1$ wyrażonego w formie warunkowej. Natomiast taka fattispecie, w której wolą podmiotu jest wywołanie zawieszenia powstania węzła aż do spełnienia się przyszłego wydarzenia - chociaż 
z tym w myśl tego, co twierdzą niektórzy autorzy, kwestią istotną jest udowodnienie, że warunek dotyczący przyszłości został postawiony, co z kolei oznacza, że taki dowód może doprowadzić do tego, iż małżeństwo będzie uznane za nieważne ${ }^{44}$.

Niektórzy autorzy podkreślają, że w sytuacji, gdy jakikolwiek warunek dotyczący przyszłości zostanie kategorycznie wyrażony, będzie on niweczył bez wyjątku zgodę małżeńską ${ }^{45}$. Wobec tego, jeśli zastrzeżone wydarzenie będzie przyszłe, to $\mathrm{z}$ pewnością nie będzie miało żadnego znaczenia, czy warunek będzie godziwy, czy też niegodziwy albo konieczny lub niemożliwy, przyczynowy czy mieszany, ponieważ w każdym przypadku będzie powodował nieważność małżeństwa. $Z$ uwagi na to postępowanie dowodowe będzie opierało się na wykazaniu, że podmiot miał intencję postawienia warunku, która wcześniej nie została odwołana, nawet w momencie zawierania małżeństwa. Zatem taka intencja będzie wystarczająca do tego, aby zaistniała możliwość nieważności konsensu, bez względu na naturę zaistniałego wydarzenia ${ }^{46}$. Jednocześnie należy zauważyć, że uza-

bez zastrzeżenia sobie odwołalności i z prawdziwa wola zawarcia małżeństwa - jest oczywistym przypadkiem zgody warunkowej, mimo wszystko nieważnej, ale w tym przypadku wskutek włączenia warunku dotyczącego przyszłości, który z Prawa pozytywnego nie jest uznawany w obowiązującym prawodawstwie, choć był uznawany w przeszłości”.

${ }^{44}$ L. A. Robittaille, Conditioned consent: Natural law and human positive law, Studia Canonica 26 (1992), s. 75-110.

${ }^{45}$ W. Góralski, Kanoniczne prawo..., s. 205.

${ }^{46}$ Tamże. Warto zwrócić uwagę na wypowiedź Autora, w której porusza problematykę związaną z tym, czy warunek podnoszący okoliczność rozciagniętą w czasie można uznać za warunek dotyczący przyszłości. Autor przedstawia pozytywna odpowiedź, przy czym przytacza orzecznictwo Roty Rzymskiej, które zaprzecza takiej właśnie tezie. Dlatego też warto przypomnieć, że orzecznictwo rotalne pod rządami KPK z 1917 r. kwalifikowało tego typu warunek jako dotyczący teraźniejszości. Zgodnie z nim oczekiwanie na spełnienie się okoliczności rozciagającej w czasie zawiesza małżeństwo na czas nieokreślony, co z pewnością w takiej sytuacji staje się absurdem. Wobec tego Autor wyjaśnia, że przedmiot takiego warunku występuje lub nie już w samym momencie wyrażenia konsensu i jest nim właśnie wola. Zatem, jeżeli taka wola maiłaby miejsce $\mathrm{w}$ chwili zawierania umowy małżeńskiej, to byłaby od początku ważna. Autor natomiast zaznacza, że według jego opinii uzasadnienie przedstawione przez Rotę Rzymską budzi wiele wątpliwości. Z tego też względu Autor wyjaśnia, że utrzymanie takiej regulacji obecnie byłoby jego zdaniem utrudnione przede wszystkim z uwagi na intencję prawodawcy kościelnego co do usunięcia tego wszystkiego, co może ograniczać lub pomniejszać wspólnotę całego życia małżonków. W związku 
leżnienie zgody małżeńskiej przez strony od warunku dotyczącego przyszłości stanowi okoliczność istotną i z tego względu powinno być podane do wiadomości osobie przygotowującej przyszłych małżonków do sakramentu małżeństwa, i to najpóźniej w chwili wstappienia przez nich w związek małżeński. Niektórzy autorzy zaznaczają, iż: „Jest to konieczne do tego, aby można było podjąć niezbędne kroki zmierzające do tego, aby przyszłe małżeństwo było ważnie zawarte"47. Zatem wydaje się zasadne przypomnienie Instrukcji Konferencji Episkopatu Polski o przygotowaniu do zawarcia matzeństwa w Kościele katolic$\mathrm{kim}^{48}$, z której wynika, że na proboszczu ciąży obowiązek przeprowa-

z tym Autor podkreśla, że ta kategoria okoliczności, od których uzależnia się zgodę małżeńską, powinna być zakwalifikowana do warunków odnoszących się do przyszłości, powodujących nieważność małżeństwa. Pogląd wyrażony przez Autora potwierdza inny znany kanonista. Zob. L. A. Robittaille, Conditioned consent..., s. 79-80. Autorka (obrońca węzła małżeńskiego w Vancouver Regional Tribunal) zaznacza, że postawienie warunku rozciagniętego w czasie dokonuje się poprzez umowę zawartą w teraźniejszości, z tym że skutki takiej umowy zweryfikują się dopiero w przyszłości. Zdaniem Autorki niedopuszczalne jest kwalifikowanie warunku rozciagającego w czasie, jako okoliczności dotyczącej teraźniejszości, chociażby z uwagi na to, że może zdarzyć się, iż okoliczność rozciagająca w czasie może zweryfikować się pod koniec życia małżonków i wówczas pomimo zawarcia przez strony takiego małżeństwa mielibyśmy do czynienia ze stanem zawieszenia małżeństwa aż do momentu zweryfikowania się tej okoliczności. Ponadto Autorka dodaje, że nie można mieć do czynienia ze stanem zawieszenia małżeństwa, ponieważ małżeństwo jest ważne lub nieważnie zawarte.

${ }^{47}$ P. GaJda, Prawo matżeńskie Kościoła katolickiego, Tarnów 2000, s. 143.

48 Instrukcja Episkopatu Polski o przygotowaniu do zawarcia matżeństwa w Kościele katolickim z dnia 13 grudnia 1989 r., nr 36-43, w: C. KraKowiaK, L. AdAMOWICZ, Dokumenty duszpastersko - liturgiczne Episkopatu Polski (1966-1998), Lublin 1999. Warto jeszcze dodać, że do Instrukcji dołączono odpowiedni wzór protokołu z rozmów kanoniczno - duszpasterskich z narzeczonymi przed zawarciem matżeństwa. W części III noszącej tytuł: Wady oświadczenia woli zawarcia małżeństwa, w pozycji 18 znajdują się trzy pytania związane z warunkiem, na które oczywiście strony - narzeczeni powinni podać odpowiednią odpowiedź. Nie ulega wątpliwości, iż pytania te mogą ujawnić duszpasterzowi, czy strony - narzeczeni - chcą zawrzeć małżeństwo pod jakimś warunkiem. $Z$ tego też względu można przytoczyć te pytania: 1 . Czy są stawiane jakieś wymagania, od których uzależnia się zawarcie lub trwanie małżeństwa? 2. Czy wymagania nie mają formy warunku? 3. Jakie jest stanowisko drugiej strony w sprawie? Zatem duszpasterz, sporządzając protokół przedślubny, powinien poinformować strony, że od postawionego przez nie warunku może zależeć ważność małżeństwa, $\mathrm{z}$ tego też względu duszpasterz powinien zapytać każdą stronę - narzeczonych (osobno), czy nie uzależniają ważności małżeństwa, które chcą zawrzeć, od czegoś, 
dzenia i spisania protokołu przedślubnego, w którym oprócz danych osobowych strony powinny odpowiedzieć na zamieszczone pytania, z których można uzyskać odpowiedź na to, czy narzeczeni są dotknięci przeszkodami małżeńskimi, czy też w ich przypadku mogą wystapić wady oświadczeń woli, szczególnie odnośnie do zgody warunkowej.

Kończąc rozważania związane z wpływem warunku dotyczącego przyszłości na ważność małżeństwa, należałoby postawić następujące pytanie: czy małżeństwo tak zawarte jest nieważne $\mathrm{z}$ prawa natury, czy może jest nieważne też z prawa stanowionego? Odpowiadając na tę wątpliwość, należy wyjaśnić, iż w doktrynie istnieje spór na temat źródeł pochodzenia nieważności małżeństwa. Niektórzy autorzy, będący zwolennikami poglądu, według którego defekt konsensu pochodzi z prawa naturalnego, uważają, że postawienie warunku przez kontrahenta wiąże się $\mathrm{z}$ przekonaniem, iż w momencie zawierania małżeństwa nie istnieje ścisłe zobowiązanie ${ }^{49}$. Poza tym podkreślaja, że istnienie takiego typu przeświadczenia nie jest do pogodzenia ze skutecznością konsensu. Wobec tego, jeżeli nupturient stawia warunek, to wówczas nie myśli on o zawieszeniu zgody małżeńskiej, tylko o rozwiązaniu małżeństwa. $Z$ uwagi na to tę formę warunku można określić jako conditio de futuro resolutiva. Zatem można powiedzieć, że podstaw dyspozycji zawartej w kan. 1102 § 1 KPK z 1983 r. należy upatrywać w założeniu, że konsens małżeński nie może zostać zastapiony przez żadną ludzką władzę. Podobną opinię przedstawiają inni kanoniści, stwierdzając, że w przypadku zawarcia małżeństwa

na czym im w szczególnie zależy. Wobec tego, gdyby duszpasterz dowiedział się od stron, iż uzależniają lub zamierzają uzależnić swoją zgodę małżeńską od sprawy dotyczącej przyszłości, to powinien doprowadzić do odwołania takiego warunku. Gdyby natomiast jedna ze stron tego nie uczyniła, to wówczas duszpasterz nie może dopuścić do zawarcia sakramentu małżeństwa. Gdyby zaś jedna ze stron odwołała warunek, to wtedy duszpasterz musi dokonać odpowiedniego zapisu w protokole przedślubnym i może dopuścić do zawarcia małżeństwa. W przeciwnym wypadku, a więc gdyby warunek dotyczący przyszłości nie został odwołany, małżeństwo będzie nieważne. Poza tym duszpasterz powinien pouczyć narzeczonych, że stawianie przed ślubem warunków świadczy o wyrachowaniu i nie ma nic wspólnego z prawdziwą miłością. Duszpasterz powinien również wziąć pod uwagę przypadki, które uzasadniają zawarcie małżeństwa pod warunkiem, ale tylko co do przeszłości lub teraźniejszości, dlatego też w każdym przypadku powinien poinformować strony o skutkach postawionego warunku.

49 L. Notaro, Retroattivita o irretroattivita del can. $1102 \S 1$, Città del Vaticano 1993, s. 66. 
pod warunkiem co do przyszłości konsens nie istnieje z prawa naturalnego ${ }^{50}$. Należy zauważyć, że poglądy niektórych autorów stwierdzające, że przeszkoda ta pochodzi z prawa naturalnego, nie mają poparcia, natomiast większość kanonistów uważa, że tytuł ten pochodzi z prawa pozytywnego ${ }^{51}$.

Analizując sprawę wprowadzenia do KPK z 1983 r. odmiennego uregulowania małżeństwa zawartego pod warunkiem dotyczącym przyszłości, w stosunku do KPK z 1917 r. można powiedzieć, że uniknęło ono wielu kłopotliwych kwestii. KPK z 1917 r. dopuszczał możliwość zawarcia małżeństwa pod warunkiem dotyczącym przyszłości, z tym że postawiony warunek nie mógł być przeciwny istocie małżeństwa. Z kolei w przypadku postawienia warunku koniecznego, niemożliwego albo niegodziwego powodowało, iż takie warunki były uznawane za niedodane. KPK z 1983 r. natomiast sprawę małżeństwa zawartego pod warunkiem dotyczącym przyszłości reguluje w sposób prostszy, bowiem stanowi, że nie można ważnie zawrzeć małżeństwa pod jakimkolwiek warunkiem dotyczącym przyszłości. Ponadto nie ma znaczenia rodzaj warunku dotyczącego przyszłości, jaki dołączyła jedna ze stron albo obie strony do swojej zgody małżeńskiej, ponieważ i tak takie małżeństwo zostanie zawarte nieważnie.

5.2. Wpływ na ważność małżeństwa warunku odnoszącego się do przeszłości lub teraźniejszości

Postanowienie kan. $1102 \S 2$ KPK z 1983 r. stwierdza, że prawodawca kościelny będzie stosował tę samą regulację prawną do warunku dotyczącego przeszłości, jak i teraźniejszości. Z zapisów kodeksowych wynika, że postanowienie to nie rozróżnia typów warunków, jakie można dołączyć do przeszłości lub teraźniejszości. Z tego też względu można przypuszczać, iż można używać wszelkich warunków, nawet koniecznych, niemożliwych lub niegodziwych, z tym że muszą one dotyczyć przyszłości lub teraźniejszości. Ustawodawca kościelny podaje tylko jedno ograniczenie, jakim jest uzyskanie pisemnej zgody od ordynariusza miejsca w celu godziwego dołączenia jednego z tych warunków do zgody małżeńskiej, o czym informuje norma

50 G. DZIERŻon, Niezdolność do zawarcia matżeństwa jako kategoria kanoniczna, Warszawa 2002, s. 250.

51 W. GóralsKi, Kanoniczne prawo..., s. 209-210. 
kan. 1102 § 3 KPK z 1983 r. Można zatem powiedzieć, że wyrażenie zgody na dołączenie jakiegokolwiek warunku dotyczącego przeszłości lub teraźniejszości jest jak najbardziej uzasadnione, chociażby z uwagi na to, że fakt, od którego uzależnia się wyrażenie zgody, już się dokonał lub jest w trakcie realizacji i nie będzie powodował zawieszenia skuteczności konsensu. Wynika z tego, że te kategorie warunków obiektywnie nie opóźniają momentu wyrażenia zgody ${ }^{52}$. Aby zaś nie doprowadzać do obiektywnego zawieszenia, a zwłaszcza odwołalności zgody, prawodawca kościelny stwierdził, iż można uznać ważność takiego sposobu zabezpieczenia się w sytuacji wątpliwości i niepewności, których nupturient doświadcza w przedmałżeńskim procesie biograficznym.

Jednocześnie należy zaznaczyć, iż w zgodzie uzależnionej od warunku dotyczącego przeszłości lub teraźniejszości nie można dopuścić zastrzeżenia odwołania zgody w czasie subiektywnej niepewności, do czasu, kiedy strona lub strony nie upewnią się co do wydarzenia już dokonanego ${ }^{53}$. Wobec tego, gdyby zaistniała taka sytuacja, że strona

52 P. J. Viladrich, Konsens matżeński..., s. 390-391. Autor podkreśla, że: „zgoda nigdy nie pozostaje w obiektywnym stanie zawieszenia w czasie którego byłoby możliwe jej odwołanie. Wydarzenie będące przedmiotem takiego warunku już obiektywnie się dokonało, a jedynie nupturient jest w stanie subiektywnej wątpliwości lub niweczy co do jego spełnienia się (np. jeśli odbyłeś już służbę wojskową, jeżeli jesteś ślubnym dzieckiem, jeżeli to prawda, że otrzymałeś spadek, jeżeli nigdy nie byłeś żonaty, jeżeli otrzymałeś już dyplom akademicki czy zawodowy, itd.)". Poza tym Autor wyjaśnił, iż: „W okresie subiektywnej niepewności odwołanie zgody, które kontrahent faktycznie może zamierzać, powinno uważać się tak obiektywnie nieskuteczne i bez znaczenia, jak zamiar odwołania zgody wyrażonej w formie zwykłej i bezwarunkowej”.

53 P. J. Viladrich, Konsens matżeński..., s. 392-394. Autor podkreśla, że: „Do ważnego dołączenia warunku dotyczącego przeszłości lub teraźniejszości konieczny jest, po pierwsze, pozytywny akt woli, którego przedmiotem jest powiązanie skuteczności zgody w wydarzeniem wystarczająco określonym, i po drugie, by warunek ten nie był odwołany przed, lub w samym akcie zawarcia małżeństwa". Jednocześnie Autor zaznacza, że: ,Akt dołączenia warunku, tak jak i akt jego odwołania, powinien być pozytywnym aktem woli, ponieważ tylko nupturient poprzez swoją wolę może sprawić, że skuteczność jego zgody małżeńskiej przeniesie się na przyczynę zewnętrzną w stosunku do niej (...) nie spełnienie się jakiegoś wydarzenia”. Jednocześnie Autor wyjaśnia, że: „Może się zdarzyć, że ktoś, kto w ciągu znajomości przedślubnej doświadcza wielu wątpliwości czy niepewności co do jakiegoś faktu, a często co do przymiotu drugiego nupturienta, uzna zweryfikowanie się jego istnienia jako nieodzowny warunek do kontynuowania lub zerwania takiej znajomości. Nie będzie w niczym dziwnym zamiana konieczności weryfikacji faktu - czyli niepewnego przymiotu - w warunek, ponieważ 
lub strony miałyby pozytywną intencję zastrzeżenia sobie możliwości odwołania konsensu, to wtedy nie można mówić o zgodzie warunkowej wynikającej z postanowienia kan. 1102 § 1 KPK z 1983 r., tylko należy zastrzec rozerwalność wyrażoną pod pozorem warunku niewłaściwego, a to już należy do normy kan. $1102 \S 2$ KPK. Poza tym trzeba dodać, że konsens ważnie uzależniony od warunku dotyczącego przeszłości lub teraźniejszości, jako zgoda aktualnie wyrażona, jest z pewnością nieodwołalny, w myśl dyspozycji kan. 1057 $\S 2 \mathrm{KPK}$.

Istotną kwestią wymagającą rozważenia jest przede wszystkim przedmiot uzależniający akt zawarcia małżeństwa, który pomaga w odróżnieniu zwykłego warunku przedmałżeńskiego, od autentycznej zgody warunkowej. Zatem należy zauważyć, że autentyczny warunek występuje wówczas, gdy intencją stron jest uzależnienie samego istnienia małżeństwa od jakiegoś zdarzenia, choć tego typu uzależnienie wystapi dopiero przy okazji różnych niepewności dotyczących kontynuacji albo zerwania narzeczeństwa, czyli uzależnienia od nich właściwego węzła małżeńskiego, jak również nieodwołania tej intencji przed chwilą zawarcia małżeństwa. Nie będzie zgody warunkowej, gdy uzależnionym przedmiotem jest tylko i wyłącznie teraźniejsze kontynuowanie narzeczeństwa albo teraźniejsza akceptacja przyszłego ślubu, bez włączenia uzależnienia właściwego aktu zawarcia małżeństwa. Z tego też względu niektórzy autorzy podkreślają, iż należy dokładnie zbadać akty i zachowania, które są najbardziej charaktery-

zgoda formuje się poprzez relacje przedmałżeńskie, a one są skierowane na zawarcie małżeństwa. W tych przypadkach decydujące jest określenie, czy podmiot przez taki warunek chciał tylko uwarunkować kontynuację narzeczeństwa czy też decyzję o zawarciu małżeństwa, i dlatego, gdy decyduje się kontynuować relacje przedmałżeńskie lub decyduje się na ślub, uważa warunek za spełniony, czy też - przeciwnie - rozciągnął uwarunkowanie aż na sam akt zawarcia małżeństwa, to jest na właściwą zgodę małżeńską. W pierwszym przypadku to nie zgoda małżeńska jest uwarunkowana, lecz kontynuacja narzeczeństwa, lub co najwyżej zgoda na ślub. W konsekwencji to, że wydarzenie się nie spełni, albo gdyby podmiot fałszywie przypuszczał, że się spełniło, niekoniecznie naruszałoby właściwy akt zawarcia małżeństwa, w którym byłaby możliwa zgoda zwykła i bezwarunkowa. Jeżeli takie upewnienie się (choćby błędne) co do faktów lub przymiotów, które podtrzymuje przedmałżeńskie relacje i plany, ograniczyło się do uwarunkowania kontynuowania lub nie kontynuowania narzeczeństwa, po uzyskaniu odpowiedniej pewności, nawet gdyby była ona w sposób oczywisty nieuzasadniona, może być przyczyną motywującą zawarcie małżeństwa, ale nie jest samo w sobie zgodą warunkową". 
styczne dla obu intencji w czasie znajomości przedślubnej nupturientów ${ }^{54}$. Inni kanoniści natomiast zaznaczają, że uzależnienie zgody od warunku ma uzasadnioną przyczynę ${ }^{55}$. Wobec tego wszelkie watpliwości przedślubne mogą być jednym $\mathrm{z}$ elementów powstania prawdziwych warunków. W związku z tym mogą zdarzyć się sytuacje, w których próby wyjaśnienia watpliwych okoliczności okazały się niewystarczające lub został osiagnięty stan pewności, z tym że później okazał się tylko tymczasowy. Oznacza to, że im większe będzie prawdopodobieństwo zaistnienia zgody warunkowej, tym więcej będzie wątpliwości co do okoliczności mających znaczenie dla strony wstępującej w związek małżeński, a dotyczących przymiotów drugiej strony.

Wobec tego do godziwego dołączenia do zgody warunku dotyczącego przeszłości lub teraźniejszości postanowienie kan. $1102 \S 3$ KPK z 1983 r. wymaga pisemnej zgody Ordynariusza miejsca ${ }^{56}$. Prośba do

54 Tamże, s. 395.

55 W. Góralski, Kanoniczne prawo..., s. 207.

56 P. J. Viladrich, Konsens matżeński..., s. 395-396. Autor zaznacza, że: „Procedura otrzymania zgody jest niewątpliwie stosownym momentem, by Ordynariusz miejsca, wysłuchując obie strony, mógł oczyścić zgodę z warunków trywialnych, nieroztropnych, czyli bezzasadnych, niemożliwych, koniecznych a przede wszystkim niegodziwych, jak również z tych intencji, które pod pozorem formy warunkowej w rzeczywistości stanowią zastrzeżenie odwołania zgody albo zastrzeżenie rozerwalności węzła. (...) Ordynariusz miejsca powinien zatroszczyć się o zachowanie odpowiedniej tajemnicy, której wymaga prywatność nupturienta wobec osób trzecich, a nawet wobec drugiego nupturienta, czy to będzie chodzić o warunki godziwe i usprawiedliwione, czy o wydarzenia o naturze przeciwnej, jeżeli a ich ujawnienia mogłoby wypłynąć szkody i niesprawiedliwe krzywdy, których można uniknąć. (...) Proboszcz albo inny świadek kwalifikowany nie mogą asystować przy zawarciu małżeństwa, jeżeli wiedzą o istnieniu konsensu warunkowego i braku zgody Ordynariusza miejsca, gdzie małżeństwo ma być zawarte. (...) W każdym razie małżeństwo zawarte pod warunkiem dotyczącym przeszłości albo teraźniejszości bez stosownej pisemnej zgody jest ważne. (...) pisemna zgoda jest dokumentem szczególnej wagi dla udowodnienia warunku dołączonego przez pozytywną wolę do konsensu. Nawet odmówienie jej i późniejsze niegodziwe zawarcie małżeństwa nabierają doniosłego znaczenia dowodowego zgody warunkowej”. Warto jeszcze zaznaczyć, iż w myśl postanowienia kan. 134 § 1 KPK z 1983 r. „,pod nazwą ordynariusz rozumiani są w prawie, oprócz Biskupa Rzymskiego, biskupi diecezjalni oraz inni, którzy - choćby tylko czasowo - są przełożonymi Kościoła partykularnego lub wspólnoty do niego przyrównanej zgodnie z przepisem kan. 368, jak również ci, którzy w nich posiadają ogólną wykonawczą władzę zwyczajną, mianowicie wikariusze generalni i biskupi (...)”. 
Ordynariusza miejsca w sprawie zawarcia małżeństwa pod warunkiem dotyczącym przeszłości lub teraźniejszości powinna być uzasadniona poważnymi racjami, jak również powody postawienia warunku nie mogą być lekkomyślne. Nie ulega wątpliwości, że złożenie prośby do Ordynariusza miejsca na zezwolenie zawarcia małżeństwa pod warunkiem dotyczącym przyszłości lub teraźniejszości stanowi weryfikację przedmiotu warunku, ponieważ, wysłuchując obu stron, może on ustalić, czy rzeczywiście strony uzależniają zgodę od warunku ${ }^{57}$. Zgoda Ordynariusza miejsca wymagana jest tylko do godziwości, a nie do ważności małżeństwa, natomiast brak takiej zgody nie ma wpływu na ważność umowy małżeńskiej ${ }^{58}$.

Rozważania związane $\mathrm{z}$ zawarciem małżeństwa pod warunkiem dotyczącym przeszłości lub teraźniejszości należy zakończyć stwierdzeniem, że nie powoduje nieważności małżeństwa, natomiast ograniczeniem w tym zakresie jest konieczność uzyskania na zawarcie takiego małżeństwa pisemnej zgody Ordynariusza miejsca, z tym że brak takiego zezwolenia nie powoduje zamknięcia możliwości zawarcia małżeństwa. W sytuacji zaś zawarcia małżeństwa bez odpowiedniej zgody kompetentnej władzy sam akt małżeński będzie ważny, ale niegodziwy. $Z$ uwagi na to prawodawca kościelny proponuje, aby strony przed uzależnieniem małżeństwa od jakiegoś warunku porozmawiały ze sobą w celu usunięcia spornych kwestii.

\section{Małżeństwo warunkowe według Kodeksu Kanonów Kościołów Wschodnich}

\subsection{Motu proprio Crebrae allatae sunt}

Analizę zagadnienia dotyczącego małżeństwa warunkowego w ustawodawstwie katolickich Kościołów wschodnich należy rozpocząć od przypomnienia motu proprio papieża Piusa XII z dnia 12 lutego 1949 r. noszącego tytuł: De disciplina Sacramento matrimonii pro Ecclesia Orientali, które zaczyna się od słów: Crebrae allatae sunt ${ }^{59}$. Z chwilą wejścia w życie tego dokumentu straciły moc obowiązująca przepisy przeciwne temu prawu i przepisy powszechne i partykularne oraz prze-

\footnotetext{
57 T. Pawluk, Prawo kanoniczne wedtug Kodeksu..., s. 166.

58 P. Gajda, Prawo matżeńskie..., s. 144.

59 AAS 41 (1949), s. 152-219.
} 
pisy wydane na synodach i zatwierdzone przez Stolicę Apostolską ${ }^{60}$. Kodyfikacja prawa małżeńskiego Kościołów wschodnich zawiera 131 kanonów, do których dołączono następujące konstytucje papieskie: pierwszą jest Altitudo papieża Pawła III z dnia 1 czerwca 1537 r., drugą Romani Pontificis papieża Piusa V z dnia 2 sierpnia 1571 r., a trzecią Popularis papieża Grzegorza XIII z dnia 25 stycznia 1585 r. Ciekawą sprawą jest fakt, iż kodyfikacja zawarta w motu proprio Piusa XII odpowiada układowi KPK z 1917 r., zwłaszcza ta część, która zawiera problematykę dotyczącą małżeństwa, bowiem stanowi powtórzenie postanowień kodeksowych obowiązujących w Kościele łacińskim ${ }^{61}$. Warto zaznaczyć, że w Kościołach wschodnich kwestia dołączenia warunku do jakiegoś aktu prawnego nie powodowała żadnego skutku. Kościoły wschodnie postanowiły pozostać w swojej tradycji i nie przyjmować uregulowań z kościoła łacińskiego w sprawie związanej z warunkiem. Norma kan. 83 zawarta w motu proprio Crebrae allatae sunt stanowi, że: „Małżeństwo zawarte pod warunkiem jest nieważne", a więc jest odmienne niż zapis znajdujący się w KPK z 1917 r. Oznacza to, że regulacje Kościołów wschodnich nie dokonały podziałów i nie rozróżniają żadnych warunków, a nawet odmawiają ważności małżeństw zawieranych pod jakimkolwiek warunkiem.

Wobec tego nasuwa się wątpliwość dotycząca tego, co właściwie oznacza zakaz zawarty w postanowieniu kan. 83 motu proprio Crebrae allatae sunt. Niektórzy autorzy podkreślają, iż wszelkie warunki dołączone do małżeństwa mają być uważane za niedodane ${ }^{62}$. Według jednej z funkcjonujących teorii warunkiem niedodanym ma być nie

${ }^{60}$ P. PaŁKa, Nowe prawo matżeńskie w Katolickim Kościele Wschodnim, Roczniki Teologiczno-Kanoniczne 2 (1955), s. 193.

${ }^{61}$ Schemat motu proprio jest następujący: kan. 1-8 kanony wstępne; kan. 9-24 De iis quae matrimonii celebrationi praemitti debent et praesertim de publicationibus matrimonialibus; kan. 25-47 De impedimentis in tenere; kan. 48-56 De impedimentis prohibentibus; kan. 57-71 De impedimentis dirimentibus; kan. 72-84 De consensu matrimoniali; kan. 85-92 De forma celebrationis matrimonii; kan. 93-96 De matrimonio conscientiae; kan. 97-98 De temporement loco celebrationis matrimonii; kan. 99-106 De matrimonii effectibus; kan. 107-121 De separatione coniugum, kan. 122-130 De matrimonii convalidatione; kan. 131 De secundis nuptiis.

${ }^{62}$ P. PaŁKA, Sakramenty święte $w$ prawie katolickich Kościołów Wschodnich, Lublin 1979, s. 116-117. 
tylko warunek godziwy, ale również przeciwny istocie małżeństwa ${ }^{63}$. Zatem można powiedzieć, że taka interpretacja doprowadza do tego, iż w sytuacji, gdy osoba postawi taki warunek, zgodnie z przepisami prawa małżeństwo takie będzie nieważne. $Z$ kolei, jeżeli warunek był godziwy i dotyczył przyszłości lub był na pograniczu godziwości i niegodziwości, to wówczas zgodnie z prawem naturalnym małżeństwo takie będzie ważne. W związku z tym powstaje domniemanie, że w ten sposób wyrażona zgoda była pozbawiona wszelkich wad. Jeżeli natomiast zaistnieje sytuacja, że warunek nie spełnił się, to zgoda małżeńska nie będzie istniała i wtedy prawo kanoniczne takiemu małżeństwu odmówi ważności. Taka interpretacja postanowienia kan. 83 jest z pewnością najmniej akceptowana. Jednocześnie należy zauważyć, że zasada przedstawiona w normie kan. 83 zakazuje uzależniania małżeństwa od warunku, z tym że postawienie takiego warunku nie czyni małżeństwa nieważnym. Poza tym niektórzy autorzy podkreślaja, że stawianie jakichkolwiek warunków jest sprzeczne ze świętym obrzędem małżeństwa i dodają, że prawo Kościołów wschodnich zwraca większą uwagę na aspekt religijny mimo braku różnicy w pojmowaniu sakramentów przez te prawodawstwa ${ }^{64}$.

Zastanawiając się nad interpretacją postanowienia kan. 83 zawartego w motu proprio Crebrae allatae sunt, należy uwzględnić opinię jeszcze innych autorów, którzy podkreślają, że każdy warunek sprowadza nieważność zawieranego małżeństwa, czyli byłoby ono nieważne nawet wówczas, gdyby okoliczność, od której ważność małżeństwa się uzależnia już się spełniła bądź w momencie zawarcia małżeństwa już istniała ${ }^{65}$. Z kolei zwolennicy interpretacji, zgodnie z którą udowodnienie, że warunek został postawiony, doprowadzi do tego, że małżeństwo automatycznie zostanie uznane za nieważne, ignorują zasady, spośród których jedna dotyczy tego, że małżeństwo cieszy się przychylnością prawa, druga natomiast dotyczy niemożliwości zawieszenia zgody małżeńskiej ${ }^{66}$. Można to zinterpretować w taki sposób, że strona lub strony dodają do zgody małżeńskiej warunek, pomimo

${ }^{63}$ E. PrzeKop, Problem matżeństw warunkowych $w$ nowym schemacie prawa wschodniego, Zeszyty Naukowe KUL 25 (1982) nr 1, s. 32-33.

${ }^{64}$ E. Herman, De interpretatione kan. 83 Motu proprio Crebrae allatae sunt, Monitor Ecclesiasticus 76 (1951), s. 508-509.

${ }^{65}$ E. Przekop, Problem matzeństw warunkowych w nowym schemacie..., s. 29-42.

${ }^{66}$ L. A. Robitaille, Conditioned consent..., s. 99. 
tego, że ustawodawca zaznacza, jaki rodzaj warunku może być dodany (żaden), a strony nie dostosowują się do tego, czego skutkiem będzie uznanie braku zgody małżeńskiej, a w konsekwencji nieważność małżeństwa. Najbardziej znaną teorią interpretacji dyspozycji kan. 83 jest stwierdzenie, że zakaz zawierania małżeństw pod warunkiem sprowadza ten skutek, że Ordynariusz miejsca nie może zezwolić na zawarcie małżeństwa warunkowego nawet wówczas, gdyby dotyczyło warunku godziwego ${ }^{67}$.

Warto zaznaczyć, że motu proprio Crebrae allatae sunt papieża Piusa V z 1949 r. nie doprowadziło do zakończenia przygotowywanego już od 1935 r. Kodeksu Kanonów Kościołów Wschodnich z uwagi na rozpoczęcie w 1962 r. Soboru Watykańskiego II i powołania w 1972 r. przez papieża Pawła VI Komisji Papieskiej do Rewizji Prawa Kanonicznego Kościoła Wschodniego ${ }^{68}$. Zatem można powiedzieć, iż sprawa dotycząca zawarcia małżeństwa warunkowego przedstawiona $\mathrm{w}$ motu proprio Crebrae allatae sunt związana jest ściśle z tradycją katolickiego Wschodu, a także wprowadza inne i autonomiczne rozwiązanie tego zagadnienia niespotykanego $\mathrm{w}$ prawodawstwie Kościoła łacińskiego.

\subsection{Analiza kan. 826 Kodeksu Kanonów Kościołów Wschodnich}

Papież Jan Paweł II w dniu 18 października 1990 r. konstytucją apostolską Sacri Canones w liturgiczne święto św. Łukasza ewangelisty promulgował nowy Kodeks dla Kościołów wschodnich ${ }^{69}$. Geneza Kodeksu Kanonów Kościołów Wschodnich sięga czasów papieża Piusa XI, który zapoczątkował proces kodyfikacji prawa wschodniego, powołując w 1929 r. Komisję Kardynałów pod przewodnictwem Piotra Gaspparriego. Komisja opracowała materiały źródłowe i od 1930 r. zaczęła wydawać je w Fontes Codificationis Orientalis. Postanowienie kan. 826 KKKW zawiera regulacje małżeństwa warunkowego i - co ciekawe - stanowi powtórzenie normy kan. $83 \mathrm{z}$ motu proprio Crebrae allatae sunt z 1949 r. Zastanawiającym jest fakt, dlaczego w kodyfi-

${ }^{67}$ H. Graziani, Matrimonium sub conditione contrahi nequit, Ephemerides Iuris Canonici 75 (1950), s. 221-230.

${ }^{6}$ W. Góralski, Prawo małżeńskie katolickich Kościołów Wschodnich wedtug kanonów Kościołów Wschodnich, Lublin 1992, s. 5.

${ }^{69}$ Codex Canonum Ecclesiarum Orientalium, Auctoritate Ioannis Pauli PP. II promulgatus, Typis Polyglottis Vaticanis 1990. 
kacji prawa Kościołów wschodnich wprowadzono zupełnie odmienne zapisy regulacji dotyczące małżeństwa warunkowego niż w KPK z 1983 r. $^{70}$

Rozważania związane $\mathrm{z}$ nieuznawaniem przez KKKW małżeństwa zawieranego pod warunkiem należy rozpocząć od analizy prac związanych z kodyfikacją prawa dla Kościołów wschodnich. Z materiałów Komisji wynika, że według jednego z poglądów dotyczących interpretacji postanowienia kan. 826 KKKW znajdowała się opinia, według której wszystkie rodzaje warunków, jakie znajdują się w Kodeksie Prawa Kanonicznego z 1983 r., w prawie Kościołów wschodnich mają być uważane za niedodane. Inny pogląd natomiast mówi, że warunek dodany do zgody małżeńskiej powoduje nieważność małżeństwa ${ }^{71}$. Najbardziej zaś powszechnie głoszony i potwierdzony przez jurysprudencję Roty Rzymskiej uznaje w dyspozycji kan. 826 KKKW tylko zakaz małżeństwa warunkowego, na zawarcie którego nie może zezwolić Ordynariusz miejsca, nawet w sytuacji, w której chodziłoby o warunek godziwy. Ponadto kwestia samej ważności małżeństwa faktycznie zawartego jest oceniana zgodnie z ogólnymi zasadami dotyczącymi zgody warunkowej ${ }^{72}$.

${ }^{70}$ E. PrzeKoP, Problem matżeństw warunkowych w nowym ..., s. 31. Autor wyjaśnia, że w ustawodawstwie Kościołów wschodnich problematyka małżeństwa warunkowego zaczęła funkcjonować dopiero w XVIII w., z tej racji, że wzbudzała zainteresowanie tym zagadnieniem Kościół łaciński. Warto zauważyć, że na pierwszym synodzie prowincjalnym w 1872 r., który odbył się w Rumunii, problematyka małżeństw warunkowych została uwzględniona, ale nie wydano w tym zakresie żadnego aktu prawnego związanego bezpośrednio z tym zagadnieniem. Z kolei w 1882 r. na drugim już synodzie zagadnieniu małżeństw warunkowych poświęcono jeden zapis, a mianowicie kan. 724. W 1898 r., natomiast na synodzie Koptów w Aleksandrii pominięto całkowicie sprawę związaną z małżeństwami warunkowymi. Problematyka małżeństw warunkowych powróciła dopiero podczas obrad synodu dla katolickich Ormian w Rzymie w $1911 \mathrm{r}$.

${ }^{71}$ M. TInTI, Condizione esplicita e consenso implicitamente condizionato nel matrimonio canonico, Roma 2000, s. 158. Autor zaznacza, że pomimo istnienia świętości sakramentu małżeństwa, małżeństwo zawarte pod warunkiem jest nieważne. Poza tym małżonkowie powinni wyrazić wolę wstąpienia w związek małżeński w sposób bezwarunkowy, bowiem w przeciwny wypadku małżeństwo to będzie zawarte nieważnie.

72 Por. P. V. Pinto, Commento al. codice dei Canoni delle Chiese Orientali, Studium Romanae Rotae, Citta del Vaticano 2001, s. 705; E. Przekop, Problem matżeństw warunkowych w nowym..., s. 30-31. E. Przekop wyjaśnia, że w sytuacji zawarcia małżeństwa pod warunkiem należy zastosować następującą argumentację: przede wszystkim należy udowodnić, że warunek został faktycznie postawiony, następnie należy udowod- 
nić, że postawiony warunek nie ziścił się, jak również należy wskazać argumentację, która opowiada się za koniecznością postawienia warunku przeciw obowiązującemu prawu. Poza tym Autor zaznacza, że zespół konsultorów w dniu 2 czerwca 1980 r. opublikował schemat prawa małżeńskiego dla Kościołów wschodnich, a później rozesłał go do hierarchów katolickiego Wschodu i innych organów konsultacyjnych z prośbą o zaopiniowanie. W związku z tym nadesłano wiele różnych opinii związanych z kwestią małżeństwa warunkowego. Jedna grupa konsultorów opowiadała się za zachowaniem dotychczasowego postanowienia kan. 83 motu proprio Crebrae allatae sunt, zaznaczając, że dotychczasowa dyspozycja potwierdza dawną tradycję wschodnią, natomiast proponowany zapis potwierdza zakaz zawierania małżeństwa warunkowego. Wskazywano zatem, że wprowadzenie takiego uregulowania nie naruszy tradycji chrześcijańskiej Wschodu, ponieważ Kościoły wschodnie nie zajmowały się wcześniej problematyką małżeństwa warunkowego, co oznacza, że nie była znana możliwość zaskarżenia małżeństw z tego właśnie tytułu. Zwolennicy tego poglądu twierdzili, że w doktrynie wschodniej małżeństwo rozpatruje się zarówno w aspekcie prawnym, jak i religijnym. Ponadto wyjaśniaja, że aspekt prawny polega na tym, że małżeństwo pojmuje się jako kontrakt, i wtedy nic nie stoi na przeszkodzie, aby do takiego małżeństwa zastosować reguły, które dotyczą zwykłych kontraktów, ale ograniczeniem, żeby treść kontraktu nie godziła w istotę małżeństwa. Zob. P. PAŁKA, Sakramenty święte w prawie katolickich..., s. 123. - 196. Autor wyjaśnia, że w aspekcie religijnym warunek jest okolicznością, która nie powinna znajdować się podczas wyrażania zgody na zawarcie małżeństwa, bowiem jest to: ,święty obrzęd (ritus sacer), którego zewnętrznym wyrazem jest ceremonia koronowania nowożeńców przy ołtarzu, nie może pozostawać $\mathrm{w}$ zawieszeniu zanim postawiony warunek nie zweryfikuje się". Poza tym Autor zaznacza, że postanowienie kan. 85 motu proprio Crebrae allatae sunt wyjaśnia znaczenie sformułowania ritum sacrum, w któtym termin ten oznacza czynność kapłana asystującego i błogosławiącego (interventu sacedotis assistentis ac benedicenis) przy zawieraniu małżeństwa, przy czym wystarczy samo błogosławieństwo. W myśl normy kan. 85, gdyby został postawiony warunek, to nie może on zawiesić skuteczności umowy małżeńskiej, ponieważ wyrażona zgoda małżeńska natychmiast wywołuje skutki prawne, a nigdy nie jest tak, że wywołuje je potem. Zatem Autor dodaje, że gdyby strony postawiły taki warunek, który dotyczyłby przyszłości, to wówczas należałoby ponownie zawrzeć małżeństwo, bowiem takie małżeństwo byłoby nieważne. Ponadto Autor przytacza jeszcze inną opinię konsultorów, którzy stwierdzili, że małżeństwo cieszy się przychylnością prawa i z tego względu należy uznać je za ważnie zawarte do czasu, kiedy nie udowodni się czegoś przeciwnego. Przeciwnicy tego poglądu, jak zaznacza Autor, uznawali postanowienie kan. 83 za zwykłe domniemanie prawne, ponieważ: „W wypadku jakichkolwiek wątpliwości norma taka jest absolutnie zbędna, gdyż znajduje się ona w jednym z pierwszych kanonów motu proprio Crebrae allatae sunt, mianowicie w kan. 3, gdzie wyraźnie stwierdza się, że in dubio standum est pro validitate matrimonii, donec contrarium probetur, nie zachodzi więc potrzeba ponawiania tej zasady po raz drugi; nadto zwykły zakaz dołączony do prawa, bez jakiejkolwiek sankcji kanonicznej, znaczy niewiele". Innym jeszcze argumentem konsultorów, które przytoczył Autor, było to, że w sytuacji stwierdzenia za- 
Wobec tego warto przypomnieć stwierdzenia konsultorów zajmujących się nowym schematem prawa małżeńskiego dla Kościołów wschodnich, którzy uważali, że gdyby postanowienie kan. 1102 KPK z 1983 r. miało obowiązywać katolików wschodnich, to nie mogłoby ono mieć zastosowania w sytuacji występowania warunku dotyczącego przyszłości, chociażby z tej racji, że taki warunek zawiesza ważność małżeństwa do chwili jego zrealizowania się ${ }^{73}$. Zatem należy zauważyć, że postanowienie kan. 1102 § 1 KPK z 1983 r. nie może być zastosowane do małżeństwa zawartego zgodnie z kanoniczną formą wschodnią, bowiem zgoda umawiających się stron nie jest wystarczająca do zaistnienia małżeństwa z uwagi na to, że wymagana jest obecność kapłana, żeby małżeństwo mogło dojść do skutku. Tak więc postawienie warunku dotyczącego przyszłości podczas zawierania małżeństwa doprowadzi do zawieszenia ważności małżeństwa aż do momentu spełnienia się postawionego warunku. Norma kan. 85 motu proprio Crebrae allatae sunt stwierdza, że postawiony warunek zawieszałby także ritus sacri, który wywołuje skutki zaraz po obrzędzie, ale nigdy potem. W związku z tym w sytuacji, gdyby postawiony warunek dotyczący przyszłości spełnił się, należałoby znowu z udziałem kapłana ponowić zawarcie małżeństwa ${ }^{74}$. Zatem w sytuacji powstania warunku dotyczącego przeszłości lub teraźniejszości ritus sacer będzie wywierał wszelkie skutki prawne i religijne natychmiast lub nie, w zależności od tego, czy to, co zostało zastrzeżone, istnieje czy nie ${ }^{75}$. Rozważania związane z postanowieniem kan. $826 \mathrm{KKKW}$ dotyczącym małżeństw warunkowych należy zakończyć konkluzją, że zapis ten stanowi o bezwzględności nieważności każdego, zawartego pod warunkiem małżeństwa, bez względu na to, czy warunek dotyczy teraźniejszości, przeszłości czy też przyszłości. Poza tym nie ma tu znaczenia, czy warunek ten jest godziwy i dozwolony. Oznacza to, iż postanowienie kan. 826 usuwa przyczyny nieważności małżeństw, jak

istnienia warunku, który nie spełnił się, zgoda, która została wcześniej wyrażona, nie pociaga za sobą żadnych skutków prawnych i z tego powodu nie może być uzupełniona. Gdyby zaś taka sytuacja zaistniała, to wówczas wierni - katolicy wschodni - mają prawo zaskarżyć nieważność takiego małżeństwa zgodnie z zasadami znajdującymi się w Kodeksie dla kościoła zachodniego.

73 Por. L. A. Robittaille, Conditioned consent..., s. 102.

74 E. Przekop, Problem matżeństw warunkowych w nowym ..., s. 196-197.

75 P. PAŁKA, Sakramenty święte w prawie katolickich ..., s. 123. 
również likwiduje możliwość wielu nadużyć. Zasadne natomiast wydaje się zakończenie rozważań stwierdzeniem niektórych kanonistów, że: „Rozwiązanie przyjęte w Kościele łacińskim nie jest szczęśliwe, ponieważ zwiększa się ilość małżeństw nieważnych z powodu prawa unieważniającego, co nie likwiduje możliwych nadużyć, a stwarza jeszcze łatwiejszą do nich okazję. Dlatego najrozsądniejsze wydaje się rozwiązanie prawa wschodniego"76.

\section{Zakończenie}

Zrozumienie instytucji małżeństwa warunkowego rozpoczęto od jej historii i rozbieżności poglądów wśród autorów zajmujących się tym zagadnieniem. Wynika to zwłaszcza z odmiennej koncepcji przyjmowanej przez kanonistów, jak również spowodowane jest różnicą okresów, w których dochodziło do wykształcania się instytucji małżeństwa warunkowego. W XII w. wykształciło się pojęcie małżeństwa kanonicznego w Kościele łacińskim, a dopiero w XVIII w. w ustawodawstwie Kościołów wschodnich. Z historii instytucji małżeństwa zawieranego warunkowo wynika, że prawo kanoniczne opowiadało się za przestrzeganiem zasady konsensualności umowy małżeńskiej, jako zgodnego aktu woli i wolnego od wszelkich wad prawnych. I chociaż koncepcja ta podupadła u podstaw dopuszczenia przez ustawodawstwo kościelne możliwości warunkowego zawarcia małżeństwa, jako pewnego rodzaju odstępstwa od zasady konsensualności umowy małżeńskiej, to tezę tę z pewnością uzasadnia jej wielowiekowa tradycja kanoniczna. Wyjątkiem natomiast jest prawodawstwo Kościołów wschodnich, które nigdy nie dopuszczało możliwości warunkowego zawarcia małżeństwa. Z uwagi na to interpretacja nowej regulacji warunku powinna przedstawiać się na tle precedensów doktrynalnych i prawnych, w których uproszczonym rozwiązaniem jest postanowienie kan. 1102 KPK z 1983 r. i norma kan. 826 KKKW. Problematyka instytucji małżeństw zawieranych warunkowo jest zarówno ciekawa, jak i trudna z tej racji, że brak jest szczegółowej monografii zawierającej analizę wyroków zapadłych w trybunałach kościelnych z tytułu uzależnienia zgody małżeńskiej od postawionego warunku.

${ }^{76}$ M. Al. Żurowski, Kanoniczne prawo małżénskie okresu..., s. 297. 


\section{Marriage conditionally in the light of the Code of Canon Law of 1983 and the} Code of Canons of the Eastern Churches of 1990

The issue of marriages conditionally institutions is complex. Marriage is provided by the doctrine of the Catholic Church has always been difficult and causing divergence of views in this area. Therefore, the expression of marital consent condition can result in the nullity of marriage, and therefore is considered to be defects in consent. Code of Canon Law of 1983 addicted validity of marriage on the type of condition. Code of Canons of the Eastern Churches of 1990 denied the validity of any marriage contained the condition. 